\title{
Review \\ Non-Coding RNAs in Cancer Diagnosis and Therapy: Focus on Lung Cancer
}

\author{
Patricia Le, Giulia Romano, Patrick Nana-Sinkam and Mario Acunzo *
}

Citation: Le, P.; Romano, G. Nana-Sinkam, P.; Acunzo, M. Non-Coding RNAs in Cancer Diagnosis and Therapy: Focus on Lung Cancer. Cancers 2021, 13, 1372. https://doi.org/10.3390/ cancers 13061372

Academic Editor:

Triantafillos Liloglou

Received: 11 February 2021

Accepted: 11 March 2021

Published: 18 March 2021

Publisher's Note: MDPI stays neutral with regard to jurisdictional claims in published maps and institutional affiliations.

Copyright: (c) 2021 by the authors. Licensee MDPI, Basel, Switzerland. This article is an open access article distributed under the terms and conditions of the Creative Commons Attribution (CC BY) license (https:/ / creativecommons.org/licenses/by/ $4.0 /)$.
Division of Pulmonary Diseases and Critical Care Medicine, Department of Internal Medicine, Virginia Commonwealth University, Richmond, VA 23298, USA; patricia.le@vcuhealth.org (P.L.); giulia.romano@vcuhealth.org (G.R.); patrick.nana-sinkam@vcuhealth.org (P.N.-S.)

* Correspondence: mario.acunzo@vcuhealth.org

Simple Summary: Researchers have spent nearly two decades unraveling the roles of non-coding RNAs in cancer biology. In recent years, deep transcriptomic profiling of tissue and circulating non-coding RNAs in cancer patients have elucidated non-coding RNAs as potential biomarkers that can inform cancer diagnosis and prognosis. Clinical trials have also begun examining non-coding RNA-based drugs as adjuncts to traditional chemotherapeutics. Overall, our review is structured to provide an overview of non-coding RNAs in cancer biology, diagnostics, and therapeutics, focusing on lung cancer.

Abstract: Over the last several decades, clinical evaluation and treatment of lung cancers have largely improved with the classification of genetic drivers of the disease, such as EGFR, ALK, and ROS1. There are numerous regulatory factors that exert cellular control over key oncogenic pathways involved in lung cancers. In particular, non-coding RNAs (ncRNAs) have a diversity of regulatory roles in lung cancers such that they have been shown to be involved in inducing proliferation, suppressing apoptotic pathways, increasing metastatic potential of cancer cells, and acquiring drug resistance. The dysregulation of various ncRNAs in human cancers has prompted preclinical studies examining the therapeutic potential of restoring and/or inhibiting these ncRNAs. Furthermore, ncRNAs demonstrate tissue-specific expression in addition to high stability within biological fluids. This makes them excellent candidates as cancer biomarkers. This review aims to discuss the relevance of ncRNAs in cancer pathology, diagnosis, and therapy, with a focus on lung cancer.

Keywords: non-coding RNA; lung cancer; cancer diagnosis; cancer therapy

\section{Introduction}

The majority of the human transcriptome encodes for non-protein coding RNAs from intergenic, antisense, or overlapping regions to coded genes [1,2]. To date, it is estimated that non-coding RNAs (ncRNAs) account for approximately $98 \%$ of the human genome [3,4], with only a small fraction of this information having been studied thus far. Accordingly, investigations examining the "dark matter" [5] or non-coding transcriptome have risen exponentially within the last several decades (see Figure 1). Initially, these ncRNAs were believed to be "transcriptional noise", [6] but recent advances in RNA sequencing technology and bioinformatics [7] have dispelled this notion by identifying the diverse contributions of ncRNAs on gene regulation. Although there are mixed opinions on the impact of ncRNAs on overall cellular activity [8], researchers remain optimistic about the importance of their roles in tumorigenesis and malignancy. In this paper, the role of ncRNAs in cancer pathophysiology, diagnostics, and therapeutics will be reviewed with an added focus on lung cancers. 


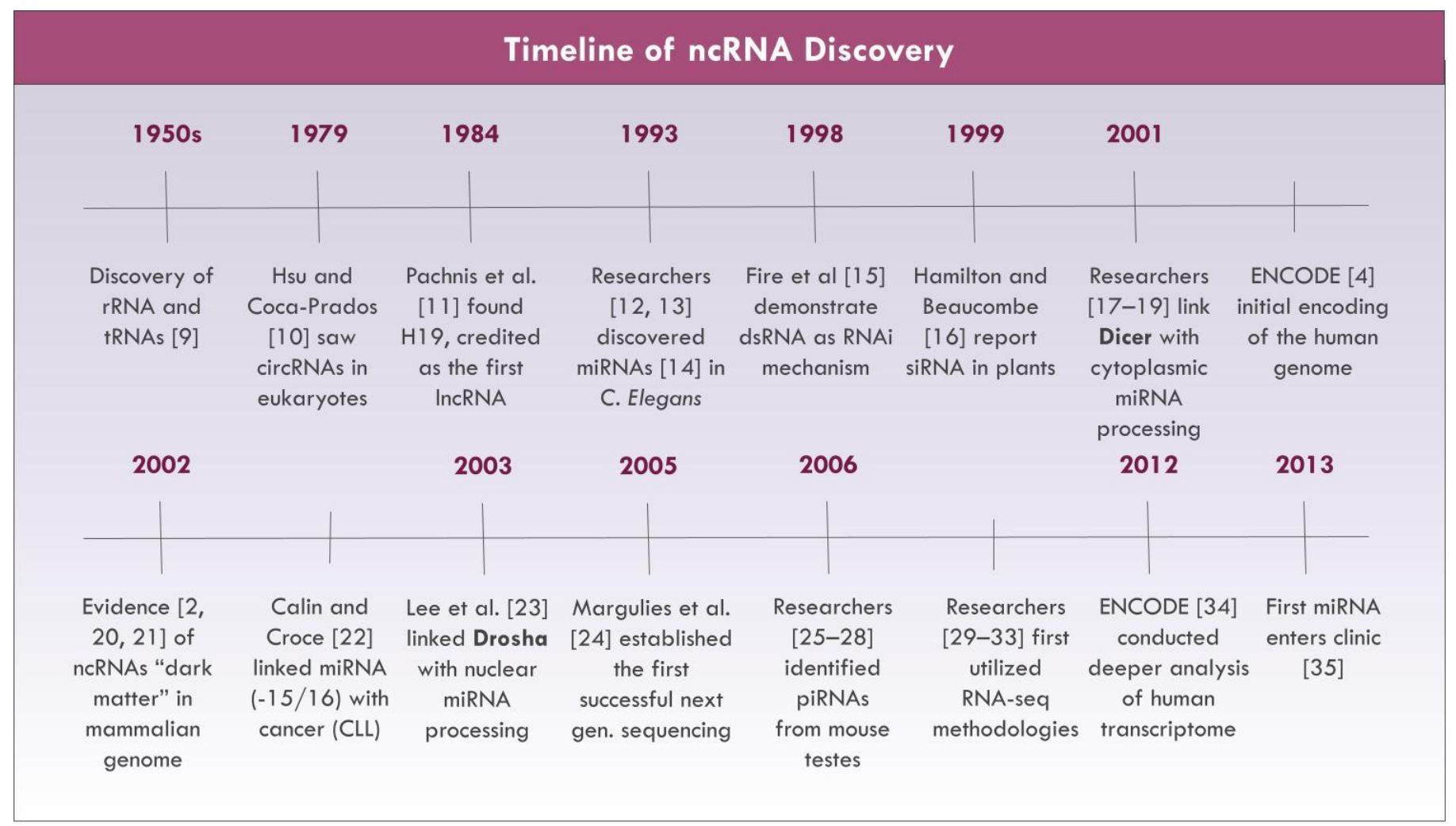

Figure 1. Non-coding RNA (ncRNA) research milestones [2,4,9-35].

\section{Classifications of Non-Coding RNAs}

Novel RNAs are discovered through various methodologies, including cDNA libraries, tiling arrays, and high-throughput sequencing technologies [36,37]. RNA sequencing (RNA-seq) technologies, in particular, have been invaluable in the elucidation of novel ncRNAs [38,39].

Classical housekeeping ncRNAs include ribosomal RNA (rRNA), transfer RNA (tRNA), small nuclear RNA (snRNA), and small nucleolar RNA (snoRNA) [40,41]. rRNAs and tRNAs have indispensable roles in protein synthesis: rRNAs are the primary RNA component of ribosomes, while tRNAs bring the correspondent amino acid per codon for building the primary peptide chain [41]. snRNAs are at the core of spliceosomes, which catalyze intron excision for mRNA maturation [41]. snoRNAs are involved in the post-transcriptional modifications and maturation of several RNA classes (e.g., rRNAs, snRNAs) [42].

The length of ncRNAs span from the magnitude of a few nucleotides to several thousands of nucleotides. Small non-coding RNAs (sncRNAs) are 20-30 nucleotides in length $[43,44]$ and encompass microRNAs (miRNA), endogenous small-interfering RNA (endo-siRNA), and PIWI-interacting RNA (piRNA) [4,45-47]. These sncRNAs are involved with RNA interference (RNAi) whereby they form complexes with Argonaute family proteins to target and silence complementary mRNA transcripts [46]. Specifically, miRNAs and endo-siRNAs form RNA-induced silencing complexes (RISCs) with Argonaute proteins [46], while piRNAs interact with the PIWI clade of Argonaute proteins to form regulatory complexes [48]. Both miRNAs and siRNAs have been shown to target genes in a wide range of biological pathways and, as such, they have diversified functional consequences on cellular activity. The functions of piRNAs are more specific as they have been linked to regulating germline development and maintenance by preserving genome integrity [48]. 
Long non-coding RNAs (lncRNAs) have lengths greater than 200 nucleotides and include long intergenic non-coding RNAs (lincRNAs), long enhancer ncRNAs, and transcribed ultraconserved regions (T-UCRs) [4,36,45,49-52]. Other ncRNAs that are traditionally classified as IncRNAs include circular RNAs (circRNAs) [36], which are singlestranded closed loops [53] that range from 100 to 10,000 nucleotides in length [40], and pseudogenes [54,55], which are derived from previously coding transcripts. The functions of lncRNAs are more varied. In the nucleus, lncRNAs can regulate gene expression at both the transcriptional and epigenetic levels by altering transcriptional machinery activity and chromatin assembly, respectively [39]. In the cytoplasm, lncRNAs can regulate post-transcriptional mRNA processing, posttranslational protein modifications, and cell signaling pathways [39].

This review will mainly focus on select sncRNA and lncRNAs in cancer (Figure 2).

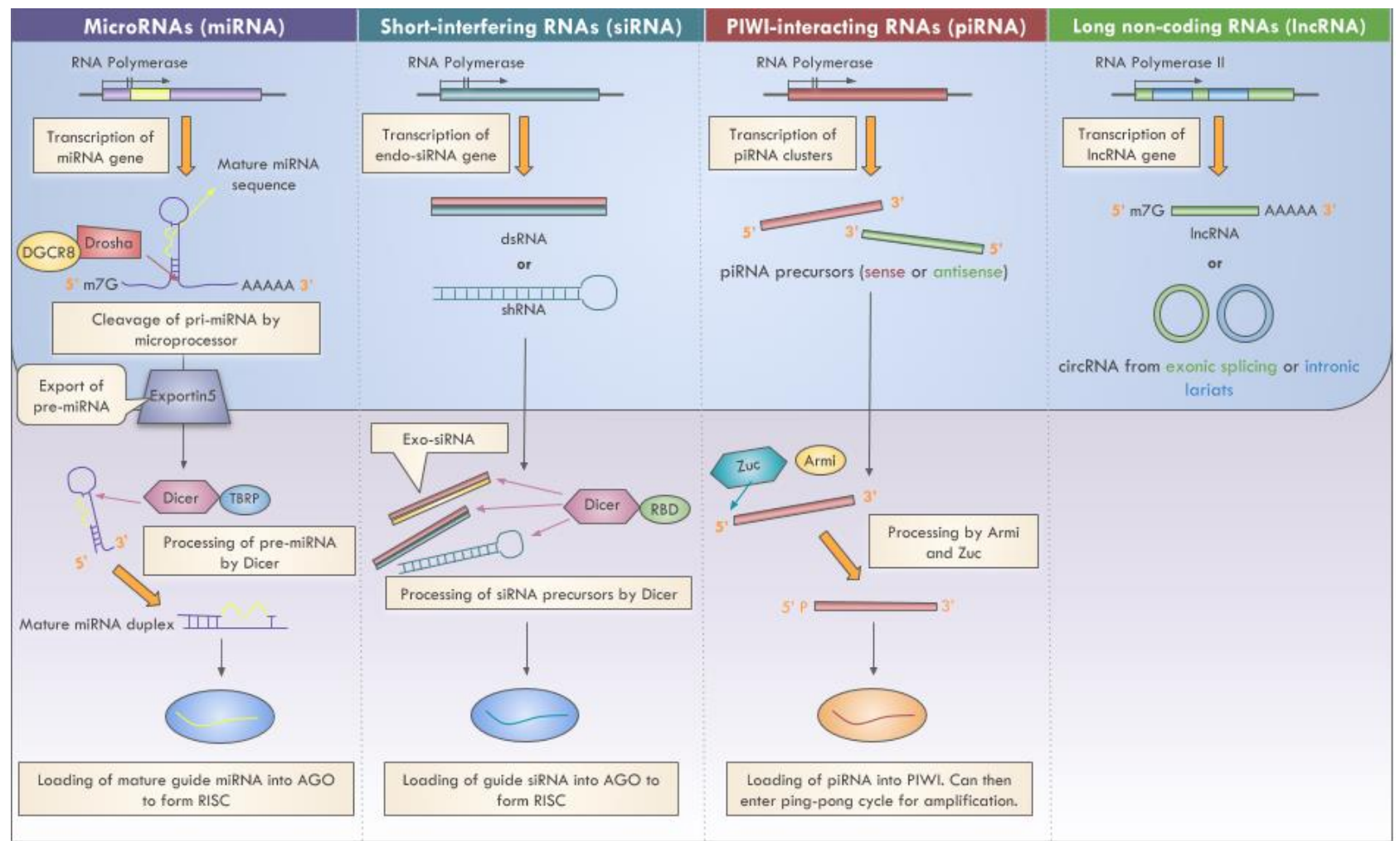

Figure 2. Biogenesis of select ncRNAs.

\section{The Role of Non-Coding RNAs in Cancer Biology}

In 2002, a pioneering study by Calin and Croce [22] identified a link between dysregulated miR-15a and miR-16-1 with chronic lymphocytic leukemia (CLL). Many ncRNAs have since been implicated in hallmark cancer processes [56,57]. Although only a few well-studied ncRNAs are discussed, it is worth noting that studying a single biomolecule or pathway in isolation simplifies the biological reality where many cancer pathways interplay and influence each other [40]. Furthermore, a single ncRNA can be involved in regulating multiple biological pathways [58], and can interact with a variety of DNA, mRNAs, proteins, and other ncRNAs $[40,59,60]$. This exemplifies the complexity of deducing the precise roles of ncRNAs in human cancer pathology.

\subsection{Overview of ncRNAs in Cancer}

With advances in RNA sequencing (RNA-seq) technologies, the transcriptome of cancer cells and tissues can be analyzed [38]. With this technology, the sequences and frequencies of dysregulated ncRNAs in cancers can be obtained [38,39]. 
Regarding the contributions of ncRNAs to human cancers, miRNAs are by far the most studied [61,62]. To uncover the cancer-related functions of miRNAs, numerous in vitro and in vivo experiments implement strategies of over- and under-expressing the miRNA(s) of interest. This is followed by examination of the induced biological activity through various functional assays [36,55]. Elucidating the mRNA targets of miRNAs through using in silico approaches (e.g., TargetScan, miRanda) or high-throughput sequencing also aids in the derivation of their function [36,63]. Interestingly, in conjunction with inducing RNAi, recent studies have shown that secreted miRNAs can also act as ligands for triggering prometastatic inflammatory responses within the tumor microenvironment $[64,65]$. The functions of piRNAs in cancer are less understood. Most studies thus far have examined the PIWI clade of Argonaute proteins independent of piRNAs, but more recent studies have examined the PIWI/piRNA interaction in cancers $[48,66,67]$. There is a general upregulation of these complexes in cancers, which has been linked to aggressive cancer phenotypes [48]. There are several well-established lncRNAs that have been linked to cancers (e.g., HOTAIR, H19, MEG3, MALAT1). They have varied roles in driving cancers and are specifically involved in post-transcriptional gene regulation, cell proliferation, metastasis, angiogenesis, and drug response. Overall, through the insight of functional studies, the effect of ncRNAs can be broadly categorized as being either tumorigenic or tumor suppressive, although some ncRNAs can demonstrate both activities in a contextdependent manner $[68,69]$. Some dysregulated ncRNAs are shown in Table 1.

Table 1. Dysregulated ncRNAs in cancer.

\begin{tabular}{|c|c|c|c|c|c|}
\hline Variable & ncRNA & Mechanism & Dysregulated in & Functions in Cancers & Ref. \\
\hline \multirow{10}{*}{$\operatorname{lncRNA}$} & HOTAIR & Oncogene & $\begin{array}{l}\text { Endometrial, lung, ovarian, } \\
\text { prostate, thyroid }\end{array}$ & $\begin{array}{l}\text { Interacts with PRC2 to methylate and silence } \\
\text { tumor suppressor genes }\end{array}$ & [70-72] \\
\hline & MALAT1 & $\begin{array}{l}\text { Oncogene }+ \\
\text { tumor } \\
\text { suppressor }\end{array}$ & $\begin{array}{l}\text { Breast, endometrial, lung, } \\
\text { ovarian, prostate, thyroid }\end{array}$ & Alternative splicing, metastasis & {$[71,73,74]$} \\
\hline & MEG3 & $\begin{array}{l}\text { Tumor } \\
\text { suppressor }\end{array}$ & $\begin{array}{l}\text { Breast, colorectal, gastric, liver, } \\
\text { lung, ovarian, prostate }\end{array}$ & $\begin{array}{l}\text { Regulates proliferation, angiogenesis, epithelial- } \\
\text { to-mesenchymal transition, drug sensitivity }\end{array}$ & {$[71,75,76]$} \\
\hline & H19 & $\begin{array}{l}\text { Oncogene }+ \\
\text { tumor } \\
\text { suppressor }\end{array}$ & $\begin{array}{l}\text { Bladder, breast, colorectal, } \\
\text { endometrial, ovarian, prostate }\end{array}$ & $\begin{array}{l}\text { Induces cell survival pathways in response to } \\
\text { stress, epithelial-to-mesenchymal transition } \\
\text { (primary site) and mesenchymal-to-epithelial } \\
\text { transition (secondary site) }\end{array}$ & [77] \\
\hline & BRAFP1 & Oncogene & Lymphoma & Activates BRAF & [78] \\
\hline & NANOG & Oncogene & $\begin{array}{l}\text { Breast, colorectal, hepatocellular, } \\
\text { leukemia, lung, } \\
\text { pancreatic, prostate }\end{array}$ & $\begin{array}{l}\text { Sustains cell-renewal and confers stem cell-like } \\
\text { properties. Involved with proliferation, } \\
\text { migration, invasion, drug resistance }\end{array}$ & [79] \\
\hline & OCT4 & Oncogene & Liver, lung, pancreas & $\begin{array}{l}\text { Sustains cell-renewal and confers stem cell-like } \\
\text { properties. Involved with proliferation, } \\
\text { migration, invasion, drug resistance }\end{array}$ & [80] \\
\hline & PTENP1 & $\begin{array}{l}\text { Tumor } \\
\text { suppressor }\end{array}$ & Breast, gastric, prostate, renal & Sponges microRNAs that target PTEN & {$[55,71,81-84]$} \\
\hline & circPRKCI & Oncogene & Glioma, lung & $\begin{array}{l}\text { Promotes proliferation and migration by sponging } \\
\text { tumor suppressing miRNAs (e.g., miR-545) }\end{array}$ & {$[85,86]$} \\
\hline & circHIPK3 & Oncogene & $\begin{array}{l}\text { Breast, colorectal, gallbladder, } \\
\text { gastric, ovarian }\end{array}$ & $\begin{array}{l}\text { Promotes cancer growth and metastasis by } \\
\text { sponging tumor suppressing miRNAs (e.g., } \\
\text { miR-7, miR-193a) }\end{array}$ & {$[87,88]$} \\
\hline \multirow{3}{*}{ piRNA } & piR-651 & Oncogene & Lung & Enhances cell viability and metastasis & [89] \\
\hline & piR-823 & $\begin{array}{l}\text { Oncogene + } \\
\text { tumor } \\
\text { suppressor }\end{array}$ & Colorectal, esophageal, gastric & $\begin{array}{l}\text { Affects cell growth, metastasis, DNA } \\
\text { methylation, apoptosis, transcriptional activity }\end{array}$ & [90-92] \\
\hline & piR-932 & Oncogene & Breast & Epithelial-to-mesenchymal transition & [93] \\
\hline \multirow[t]{2}{*}{ miRNA } & miR-15/16 & $\begin{array}{l}\text { Tumor } \\
\text { suppressor }\end{array}$ & $\begin{array}{l}\text { Chronic lymphocytic leukemia } \\
\text { (CLL), prostate cancer, } \\
\text { colorectal, pleural } \\
\text { mesothelioma }\end{array}$ & $\begin{array}{c}\text { Enhances apoptosis, reduces tumor size and } \\
\text { metastasis, and regulates } \\
\text { immunological response }\end{array}$ & [94-97] \\
\hline & $\operatorname{miR}-29$ & $\begin{array}{l}\text { Tumor } \\
\text { suppressor }\end{array}$ & $\begin{array}{l}\text { Breast, head and neck, } \\
\text { pancreatic, prostate, liver, } \\
\text { lung, pancreas }\end{array}$ & $\begin{array}{c}\text { Induces senescence and apoptosis. Mitigates } \\
\text { against cancer metabolism proliferation, } \\
\text { migration, and invasion }\end{array}$ & [98-105] \\
\hline
\end{tabular}


Table 1. Cont.

\begin{tabular}{|c|c|c|c|c|c|}
\hline Variable & ncRNA & Mechanism & Dysregulated in & Functions in Cancers & Ref. \\
\hline & miR-34 & $\begin{array}{l}\text { Tumor } \\
\text { suppressor }\end{array}$ & $\begin{array}{l}\text { Breast, glioblastoma, lung, } \\
\text { pancreatic, prostate }\end{array}$ & $\begin{array}{l}\text { Activated by p53. Affects proliferation, } \\
\text { apoptosis, differentiation, } \\
\text { epithelial-to-mesenchymal transition, } \\
\text { invasiveness, and metastasis }\end{array}$ & {$[71,106-111]$} \\
\hline & $\begin{array}{l}\text { miR-200 } \\
\text { family }\end{array}$ & $\begin{array}{l}\text { Tumor } \\
\text { suppressor }\end{array}$ & $\begin{array}{l}\text { Breast, ovarian, lung, pancreatic, } \\
\text { prostate, renal }\end{array}$ & $\begin{array}{l}\text { Disrupts epithelial-to-mesenchymal transition, } \\
\text { invasiveness, differentiation, and metastasis } \\
\text { Silences oncogenes (e.g., RAS), decreases }\end{array}$ & $\begin{array}{l}{[11,71,104} \\
110]\end{array}$ \\
\hline & let7 & $\begin{array}{l}\text { Tumor } \\
\text { suppressor }\end{array}$ & $\begin{array}{l}\text { Breast, colorectal, gastric, liver, } \\
\text { lung, renal, thyroid }\end{array}$ & $\begin{array}{l}\text { stemness of cancer cells, regulates cell cycle and } \\
\text { signaling pathways, inhibits } \\
\text { epithelial-to-mesenchymal transition }\end{array}$ & {$[110,112,113]$} \\
\hline & miR-21 & Oncogene & $\begin{array}{l}\text { Brain, breast, endometrial, liver, } \\
\text { lung, pancreatic, prostate, } \\
\text { thyroid }\end{array}$ & $\begin{array}{l}\text { Induces cell proliferation pathways, metastasis, } \\
\text { and regulates apoptosis }\end{array}$ & {$[71,104,114]$} \\
\hline & $\operatorname{miR}-155$ & Oncogene & $\begin{array}{l}\text { Breast, cervical, colorectal, } \\
\text { leukemia, liver, lung, pancreatic, } \\
\text { thyroid }\end{array}$ & $\begin{array}{c}\text { Implicated in promoting cell survival and } \\
\text { proliferation, anti-apoptosis, metabolic shift } \\
\text { (Warburg effect) }\end{array}$ & {$[104,110,115]$} \\
\hline & $\begin{array}{l}\text { miR-17-92 } \\
\text { cluster }\end{array}$ & Oncogene & $\begin{array}{l}\text { Breast, colorectal, head and } \\
\text { neck, leukemia, lung, } \\
\text { lymphoma, pancreatic, renal }\end{array}$ & $\begin{array}{l}\text { Functions with C-MYC and transcriptional } \\
\text { regulation more broadly. Regulates proliferation, } \\
\text { apoptosis, angiogenesis }\end{array}$ & {$[110,116,117]$} \\
\hline & $\begin{array}{c}\mathrm{miR}- \\
221 / 222\end{array}$ & $\begin{array}{l}\text { Oncogene + } \\
\text { tumor } \\
\text { suppressor }\end{array}$ & $\begin{array}{l}\text { Breast, endometrial, } \\
\text { glioblastoma, hepatocellular, } \\
\text { pancreatic, prostate, thyroid }\end{array}$ & $\begin{array}{l}\text { Targets tumor suppressors. Induces cell } \\
\text { proliferation, drug resistance }\end{array}$ & {$[104,118,119]$} \\
\hline
\end{tabular}

Collectively, a variety of genetic and epigenetic factors can explain the deregulation of these ncRNAs in cancers, including gene amplification or deletion $[22,62,120]$, transcriptional repression [121], abnormal biosynthesis [122-124], alternative splicing [125], and epitranscriptome modifications or "RNA editing" [59,126,127] (see [127] for review), with the latter encompassing nucleotide substitutions [127], methylation [128], and acetylation [129]. Furthermore, IncRNAs, especially circRNAs, can function as competitive endogenous RNAs (ceRNAs) against mRNAs for miRNA binding [53]. This prevents miRNAs from executing their regulatory functions [130]. For example, H19 has binding sites for let-7 that allow it to "sponge" or reduce let-7 availability for target mRNAs [130].

\subsection{1. miRNAs Dysregulated in Cancer}

The first miRNAs connected to human cancers were miR-15a and miR-16-1. These miRNAs are commonly downregulated in CLL as a consequence of a chromosomal deletion localized at 13q14 [22]. Moreover, defective DROSHA processing can also reduce levels of miR-15/-16 [131]. Impaired miRNA processing and lowered expression of mature miRNAs are generally observed in cancers [122-124]. Functionally, miR-15a and miR-16-1 target B cell lymphoma 2 (Bcl2), an anti-apoptotic protein [94], and Cdc2 and Anxa2, which are cell cycle regulators [95]. Accordingly, the restoration of miR-15a and miR-16-1 significantly increases apoptosis in vitro [94], and reduces tumor size [95] and metastasis [96] in vivo. The miR-15/-16 cluster further mediates immunological response by negatively regulating T-cell differentiation, survival, and memory [132]. Since their initial connection to CLL, this cluster has been linked to other cancers as well $[96,97,133,134]$. Similarly, miR-29, another tumor suppressor, triggers senescence [135] and apoptosis in malignant cells. It targets Mcl-1, an anti-apoptotic protein of the Bcl family [98] that is commonly elevated in cancers [136-138]; DNMT3, a demethylase; and CDK6, a cell cycle regulator [100]. miR-29 is further associated with increased p53 activity [99]. A reduction in miR-29 expression is observed in a variety of human cancers [99,101-103]. Likewise, miR-34 has been linked with p53 activity [106-109]. Under normal conditions, physiological stress induces p53, which then acts as a transcriptional activator of numerous genes, including the miR-34 family [106]. The miR-34 family has been demonstrated to target cell cycle activators such as CDK4 and MET [106] along with anti-apoptotic factors such as Bcl2 [107]. Therefore, miR-34 is broadly associated with regulating numerous tumorigenic processes, including proliferation, apoptosis, epithelial-to-mesenchymal transition (EMT), invasiveness, 
differentiation, and metastasis $[109,139]$. Some additional highly characterized tumor suppressor miRNAs include the miR-200 family, which disrupts EMT by targeting E-cadherin transcriptional repressors such as ZEB1 [112,140], and the Let-7 family, which silences oncogenes such as RAS [141].

There are also several highly studied oncomiRs, including miR-21 [114,142-144], miR155 [144,145], the miR-17-92 family [116,146,147], and miR-221/222 [118]. Mechanistically, these oncomiRs can function synergistically with other oncogenes (e.g., c-myc) [121], or they can directly target tumor suppressor genes (e.g., PTEN) $[114,118]$ such as apoptotic factors (e.g., APAF1, CASP3) [114] or negative regulators of oncogenic pathways (e.g., SHIP1) [148]. Due to their marked contributions to hallmark cancer processes, some human malignancies demonstrate oncomiR addiction in which the cancer becomes reliant on the expression of specific oncogenic miRNA(s) for tumorigenesis [149].

\subsection{2. piRNAs Dysregulated in Cancer}

The contributions of other sncRNAs, namely piRNAs, in cancer have been studied in more recent years $[48,150]$. Analogous to other sncRNAs, piRNAs form regulatory complexes with the PIWI clade of Argonaute proteins (e.g., PIWIL1, PIWIL2, PIWIL3, PIWIL4), and these complexes transcriptionally silence sequences with complementary genomic loci by [48]. In particular, the PIWI/piRNA pathway regulates germline development and maintenance by preserving genome integrity [48]. This is achieved through repressing the mobilization of transposable elements [48,151]. Characteristics of germ cells, such as rapid proliferation and continual self-renewal, are shared with cancer cells, prompting researchers to examine germline-specific factors in connection to cancer [151]. Early investigations focused on the contributions of dysregulated PIWI, rather than piRNAs, in cancers [151]. The consensus of the findings so far is that there is an upregulation of PIWI family members in cancers derived from both gonadal [66] and somatic cells $[48,67,152]$. PIWIL1 upregulation in pancreatic cancer has been physiologically linked to activating anaphase promoting complex (APC), which induces metastasis in a piRNA-independent fashion [152]. However, a similar study by Genzor and colleagues [153] reports that PIWIL1 upregulation in colon cancer cells results in a lack of functional PIWIL1/piRNA complexes with no observable piRNA-independent functions of PIWIL1. More recent efforts have begun examining the combined role of PIWI/piRNA complexes in cancers since these complexes may prevent mutations and subsequent genome instability due to transposon mobilization [48]. Upregulation of PIWI/piRNAs in human cancers have been frequently reported $[48,66,67]$, where elevated PIWIs is associated with increased cancer aggressiveness [48]. These findings suggest that PIWI/piRNA silencing of transposon mobilization is not sufficient to explain their roles in cancer pathology [48]. Moreover, similar to miRNAs, aberrant expression of piRNAs, such as piR-651, piR-932, and piR-823, has been associated with various hallmark cancer processes, including tumorigenesis, angiogenesis, and metastasis $[89,150,154,155]$. A bioinformatic study by Martinez and colleagues [156] suggests that piRNAs demonstrate both pan-cancer and tumor-specific expression patterns, and that subgroup-specific piRNA expression can even delineate clinical features of specific tumors. Mechanistically, piRNAs have been shown to regulate gene expression by modulating epigenetic modifications of histone deacetylation and DNA methylation [154,157]. With novel methodologies and functional assays being established (e.g., multiplex bioimaging [158]), the contributions of piRNAs in cancers will be better understood.

\subsection{3. lncRNAs Dysregulated in Cancer}

A large number of unique cancer-associated lncRNAs have also been identified [159]. Unlike sncRNAs, the mechanisms of lncRNAs in cancers can widely influence gene expression at the epigenetic, transcriptional, and post-transcriptional levels [55]. The Pan-Cancer Analysis of Whole Genomes (PCAWG) Consortium [159] recognizes the need for a resource detailing lncRNAs that have validated causative roles in cancer. This led to the Cancer 
LncRNA Census (CLC), a thorough compilation of 122 GENCODE-annotated lncRNA genes that have well-established cancer-related functions of which 77 are oncogenic, 35 are tumor suppressive, and 10 exhibit both activities [159]. The most widely observed lncRNAs in human cancers were found to be HOTAIR, a lncRNA encoded in the HOXC gene that interacts with Polycomb Repressive Complex 2 (PRC2), a histone methyltransferase, for methylating and silencing various tumor suppressor genes [70,72]; MALAT1, which is involved in alternative splicing [73,74]; MEG3, a tumor suppressor that regulates cell proliferation through p53 dependent and independent pathways [75]; and H19, which induces cell survival pathways in response to stressful conditions [77].

Pseudogenes and circRNAs are often classified as lncRNAs as well. Pseudogenes are derivatives of protein-coding genes that contain a defect which renders them noncoding $[54,55,160]$. Several pseudogenes have been implicated in cancers, including BRAFP1, which drives activation of BRAF and, more broadly, the MAPK pathway $[78,160]$; NANOG and OCT4, which sustain cell-renewal and pluripotency of embryonic stem cells [160]; and PTENP1, which sponges miRNAs that target PTEN, thereby increasing PTEN expression for suppressing tumorigenesis [55,81]. CircRNAs have been described to have numerous functions in tumor immunosurveillance, immune evasion, angiogenesis, cell permeability, cell death, and extracellular matrix (ECM) remodeling [161-163]. Although certain pro-tumorigenic circRNAs can be overexpressed in cancers, such as circPRKCI in lung adenocarcinoma [85] and circHIPK3 in colorectal cancer [87], global expression of circRNAs is generally decreased in cancers [164].

\section{2. ncRNAs in Lung Cancer}

Although lung cancer incidence has declined for both males and females over the last several decades [165], lung cancer remains the prevailing cause of cancer-related deaths $[166,167]$. Histological categorization of lung cancers is divided into small cell lung cancer (SCLC), which is characterized as being a highly malignant growth with neuroendocrine features and accounts for $\sim 15 \%$ of cases, and non-small cell lung cancer (NSCLC), which accounts for the remaining $\sim 85 \%$ of cases. The latter encompasses adenocarcinoma (LUAD) [168], squamous cell carcinoma (LUSC), and large cell carcinoma (LCC) [165].

One of the earliest lncRNAs connected to lung cancer is Metastasis Associated in Lung Adenocarcinoma Transcript (MALAT1) [169]. This lincRNA transcript was discovered as a prognostic marker of metastatic disease and overall survival in LUAD patients. MALAT1 has normal expression in various human tissues [169], and is important for normal physiological and developmental processes [170]. MALAT1 is primarily localized in nuclear speckles [171], and has been strongly associated with affecting alternative splicing [73,74]. To understand its role in lung cancer, Tano and colleagues [172] silenced MALAT1 in vitro and observed impaired cell motility due to a downregulation in genes involved with extracellular matrix and cytoskeleton rearrangement (e.g., HHMR, ROD1, CCT4, CTHRC1). MALAT1 knockdown had no observable effect on proliferation [172]. Gutschner and colleagues [173] conducted loss-of-function studies in which an antisense oligonucleotide inhibitor of MALAT1 was introduced to lung cancer xenograft mice models. Faulty cell migration and fewer lung tumor nodules in vivo were observed. Increased MALAT1 is also seen in NSCLC patients with brain metastasis compared to those without, providing further support for its role in lung cancer metastasis [174]. More broadly, MALAT1 upregulation has been observed in many human cancers [73,175], which suggests that it is a ubiquitous metastatic driver. Moreover, its role in cancer is likely context-dependent since MALAT1 is shown to have anti-metastatic effects in breast cancer [175].

Many aforementioned ncRNAs also contribute to the pathogenesis of lung cancer. Takamizawa and colleagues [176] were the first to identify a reduction in the let-7 family of miRNAs in lung cancers. When the researchers overexpressed let-7f in A549 LUAD cells, they observed a marginal reduction in colony formation. In a similar report from Kumar and colleagues [177], delivery of a lentivirus vector expressing let-7g into an autochthonous 
mice model of NSCLC was shown to suppress tumor initiation. However, formed tumors also expressed let-7g, potentially as a consequence of let- $7 \mathrm{~g}$ resistance. Mechanistically, let-7g acts on Ras [168] and HMGA2 [178] in lung cancers, which is consistent with findings of reduced Ras proteins and HMGA2 in let-7g expressing tumors [177]. MiR-34b/c are also downregulated in lung cancers [179-181]. Kim and colleagues [180] conducted RNA sequencing of miR-34b/c transduced 344SQ lung cancer cells and found that these miRNAs modulate cell adhesion genes. This can explain the reduction of anchorage-independent growth in 344SQ transduced with miR-34b/c. Low miR-34c is also seen in NSCLC-derived exosomes of which accelerates invasion and migration by upregulating integrin $\alpha 2 \beta 1$ [182]. Mizuno and colleagues [181] observed reduced cell migration, invasion, and proliferation when SCLC cells were transfected with miR-34. In their study, they used an in silico approach to identify four genes (TOP2A, MELK, CENPF, SOX1) as putative targets of miR-34b. TOP2A and MELK, in particular, appear important for the high proliferation and metastatic capabilities of SCLC [181]. Cortez and colleagues [183] also report that $\mathrm{p} 53 / \mathrm{miR}-34$ act synergistically to downregulate PDL1, an immunosuppressive protein, in NSCLC. In the lungs, miR-21 is the most abundant miRNA, and its expression is further elevated in lung cancers. It affects apoptosis, proliferation, angiogenesis, and survival through inhibiting known tumor suppressor genes such as PDCD4 and PTEN [114,184-186]. Frezzetti and colleagues [186] have also shown that activation of oncogenic Ras, which is observed in a population of patients with lung cancer, induces miR-21 expression during neoplastic transformation. This suggests that miR-21 contributes to early disease development.

Upregulation of lncRNA HOTAIR in lung cancers has been linked to lymph node metastasis [187-189]. Liu and colleagues [187] conducted several in vitro experiments in which they silenced or induced HOTAIR in lung cancer cell lines with high (SPC-A1, NCI-H1975) or low (A549) HOTAIR expression, respectively. They found that HOTAIR is associated with reduced apoptosis and increased migration. Furthermore, they found that repression of HOTAIR reduced metastatic nodules in vivo. They propose that HOTAIR promotes invasion and metastasis through deregulating EMT markers such as MMPs and HOXA5. LncRNA MEG3, on the other hand, is downregulated in NSCLC [190]. Lu and colleagues [190] observed that MEG3 induction markedly decreased cell growth and colony formation in vitro, and tumor growth and weight in vivo. The tumor-suppressive effects of MEG3 are associated with p53 activation. As mentioned, circPRKCI is amplified in LUAD [85]. Qiu and colleagues [85] report that circPRKCI promotes proliferation and migration by sponging miR- 545 and miR-589, thus preventing them from inhibiting the pro-tumorigenic transcription factor E2F7.

Many ncRNAs are also involved in the acquisition of a treatment resistance phenotype. Several reports have shown that lung cancer cell lines with acquired resistance to standard chemotherapies (e.g., cisplatin, paclitaxel, gefinitib) have altered expression of hundreds of lncRNAs [191]. For instance, elevated HOTAIR and reduced MEG3 have been shown to drive cisplatin resistance in lung cancer cells [192]. In response to platinum-based chemotherapeutics (e.g., cisplatin), p53-stimulated ncRNAs (e.g., HOTAIR, PANDA) and DNA damage sensitive ncRNAs (e.g., lncRNA DDSR1) [193] can negate cell cycle arrest and elicit DNA repair, thereby overcoming drug-induced DNA damage in order to establish drug resistance [193]. Over-expression of IncRNA XIST induces autophagy, which is a protective mechanism engaged by cancer cells that ensures survival; as such, elevated XIST has been linked with poor cisplatin response [194]. Dong and colleagues [195] found that high GAS5 expressing cells (A549) exhibited increased cell death in vitro and reduced tumor formation in vivo especially when treated in combination with gefinitib, an epidermal growth factor receptor tyrosine kinase inhibitor (EGFR-TKI).

Novel ncRNAs are continuing to be linked to lung cancers. For example, Qiu and colleagues [196] recently identified lncRNA LUADT1, which is highly expressed in LUAD. LUADT1 associates with PRC2 and, together, they suppress p27 for inducing cell cycle progression. Wang and colleagues [197] also report that an upregulation of circRNA-002178 
in LUAD acts to sponge miR-34, which consequently enhances PDL1 expression for immune evasion. Li and colleagues [89] found greater expression of piR-651 in a group of 78 NSCLC patients. When this piRNA is over-expressed in A549 cells, the researchers observed enhanced cell viability and metastasis, which they propose is mediated through the cyclin D1 and CDK4 pathways. Although the functional contributions of pseudogenes in lung cancer have not been extensively researched, Stewart and colleagues [198] recently found 104 pseudogene-derived lncRNAs to be dysregulated in LUAD, which prompts further investigation on their physiological relevance in lung cancer. A summary of the ncRNAs involved in lung cancers are shown in Figure 3.

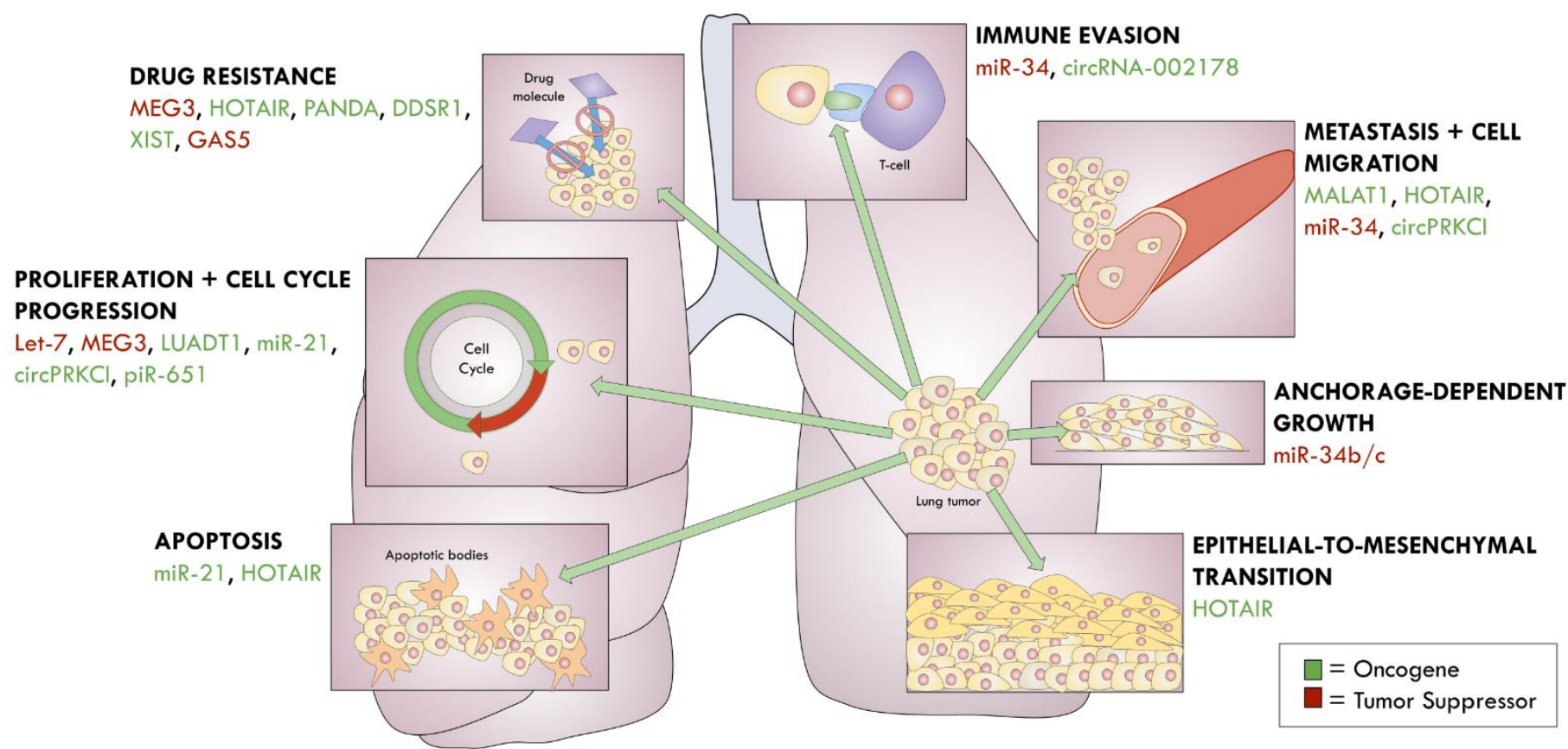

Figure 3. ncRNAs in lung cancer.

\section{The Use of Non-Coding RNAs as Cancer Biomarkers}

Collectively, ncRNAs make excellent candidate biomarkers due to their high relative stability, unique expression profiles, and straightforward characterization by PCR [37]. Therefore, several clinical trials in the past decade have been conducted to identify ncRNA biomarkers in cancer patients for the purpose of developing screening tools. It is important for the intended application of the proposed biomarker(s) to be explicitly defined as predictive, prognostic, or diagnostic, as this will influence patient cohort composition and specimen selection $[199,200]$.

Early studies of identifying tumor ncRNAs implemented the strategy of comparative profiling between normal and cancerous tissues [59]. Regarding clinical utility, tissue biopsies are well-established and informative, but invasive and not feasible for inaccessible tumors or vulnerable patients [201,202]. Furthermore, the information obtained from tissue biopsies is spatially and temporally dependent, thus it might provide an inaccurate representation of tumor heterogeneity and on-going tumor processes such as drug resistance [201-204]. Unique signatures of cancer-derived ncRNAs have been observed in circulation through biological fluids, including blood, saliva, and urine [205-207], leading researchers to explore the potential of liquid biopsies [202]. Compared to tissue biopsies, liquid biopsies are less invasive, which is optimal for screening [208] and treatment monitoring [202]. However, the frequency of circulating tumor cells (CTCs) is relatively low, and although ncRNAs can travel within bodily fluids independent of cells, free-travelling ncRNAs are prone to degradation by circulating RNAses [200,203]. An alternative approach is 
to examine ncRNAs encapsulated in extracellular vesicles (EVs) that are released by tumor cells [209]. Compared to normal cells, tumor cells have been shown to secrete a greater volume of vesicles for promoting cancer progression and pre-metastatic niche formation, thereby prompting investigations to more carefully assess their contents [200]. However, it is important to discern if altered levels of ncRNAs is confounded by differential vesicle quantities between cancer patients and healthy controls.

With the advent of high-throughput sequencing technologies such as next generation sequencing, whole genome expression profiles of patient and control samples can be compared to identify dysregulated ncRNAs [36,199]. Notably, it is unlikely that a single biomarker will be sufficient for disease characterization due to the heterogeneity of human cancers and ubiquitous expression of most ncRNAs [210,211]. Instead, bioclassifier systems composed of a panel of biomarkers may be necessary for achieving high sensitivity and specificity [210]. Large scale expression profiles of ncRNAs have already demonstrated capabilities in classifying poorly differentiated tumors, and can further contribute to our understanding of the dynamics underlying malignancies $[123,200]$. A major challenge with these bioclassifiers, however, is ensuring reproducibility. Thus, it is important to standardize sample processing and RNA extraction protocols, normalization methods, and bioinformatic analyses [199,207,211].

Although numerous promising ncRNA biomarker candidates have been identified, PCA3 is the only ncRNA to receive FDA approval as a biomarker thus far [55]. LncRNA PCA3 is uniquely upregulated in prostate cancer [212]. Hessels and colleagues [213] report an overexpression of PCA3 in urine obtained from patients with prostate cancer, thereby leading to the development of non-invasive PCA3 urine tests for clinical detection of early prostate cancer [214]. Presently, this test is being used in conjunction with other established tests (e.g., PSA blood test, TMPRSS2:ERG urine test) $[55,215,216]$.

\section{1. ncRNAs as Lung Cancer Biomarkers}

The five-year survival rate for lung cancer (19\%) ranks among the lowest for all cancers [167]. More than half of patients present with advanced-stage disease where curative therapies are limited [217,218]. Consequently, a sizable proportion of these patients are untreated [219]. Critically, lung cancer screening can improve the survival rates for high-risk patients. In screening programs, $80 \%$ of lung cancers are found at an early-stage; without screening, an overwhelming $70 \%$ of patients are diagnosed with late-stage disease [220]. Currently, the standard for lung cancer screening is a low-dose CT scan [162]. An increasing number of studies are showing that lung cancer biomarkers are promising adjuncts to CT scans for early disease detection and prognostic evaluation [221] (see Table 2). 
Table 2. ncRNA biomarkers in lung cancer.

\begin{tabular}{|c|c|c|c|c|}
\hline & Biomarker & Sample & Clinical Information & Ref. \\
\hline \multirow{12}{*}{$\begin{array}{l}\text { Disease/ } \\
\text { Diagnostic }\end{array}$} & Seven paired miRNA panel & Plasma & $\begin{array}{c}\text { Distinguishes early-stage LUAD + benign disease } \\
\text { from control }\end{array}$ & [222] \\
\hline & Five paired miRNA panel & Plasma & Distinguishes early-stage LUAD from benign disease & [222] \\
\hline & Ten paired miRNA panel & Plasma & $\begin{array}{l}\text { Distinguishes NSCLC (LUAD + LUSC) from controls } \\
\text { (healthy/endobronchitis patients) }\end{array}$ & [223] \\
\hline & SNHG1 + RMRP & Plasma & Distinguishes NSCLC from cancer-free controls & [224] \\
\hline & $\begin{array}{c}\text { Let-7b-5p, let-7e-5p, } \\
\text { miR-24-5p, and miR-21-5p }\end{array}$ & Exosome & $\begin{array}{c}\text { Distinguishes stage-I NSCLC patients from } \\
\text { healthy controls }\end{array}$ & [225] \\
\hline & $\operatorname{miR}-181-5 p+\operatorname{miR}-361-5 p$ & Exosome & Can discern LUAD from other NSCLC histologies & [225] \\
\hline & $\operatorname{miR}-320 b+\operatorname{miR}-10 b-5 p$ & Exosome & Can discern LUSC from other NSCLC histologies & [225] \\
\hline & $\begin{array}{l}\text { circRNA-0001073 + } \\
\text { circRNA-0001495 }\end{array}$ & Tissue & Differentiate LUAD and LUSC & [226] \\
\hline & miR-126 & Exosome & $\begin{array}{c}\text { Distinguishes early-stage NSCLC patients from } \\
\text { healthy controls }\end{array}$ & [227] \\
\hline & $\begin{array}{l}\text { RNA panels including } \\
\text { ncRNAs }\end{array}$ & $\begin{array}{l}\text { Tumor-educated } \\
\text { platelets }\end{array}$ & Early- and late-stage NSCLC detection & [228] \\
\hline & Edited miR-411-5p & Tissue + Exosomes & Distinguishes late-stage NSCLC from controls & [229] \\
\hline & Edited miR-99a-5p & Tissue & Distinguishes LUAD from controls & [230] \\
\hline \multirow{5}{*}{$\begin{array}{l}\text { Prognostic/ } \\
\text { Treatment }\end{array}$} & Edited miR-99a-5p & Tissue & $\begin{array}{c}\text { Informs of shorter overall survival and recurrence-free } \\
\text { survival after resection of LUAD }\end{array}$ & [230] \\
\hline & $\begin{array}{c}\operatorname{miR}-17-3 p \\
\mathrm{miR}-1268 \mathrm{~b}+\mathrm{miR}-6075\end{array}$ & Plasma & $\begin{array}{c}\text { Predicts resectable lung cancers regardless of histology } \\
\text { and staging }\end{array}$ & [231] \\
\hline & Let-7 & Tissue & Informs of poor prognosis following tumor resection & [176] \\
\hline & Let-7a + miR-155 & Tissue & Informs of overall survival & [103] \\
\hline & MALAT1 & Tissue & Informs of poor prognosis for LUSC patients & [232] \\
\hline
\end{tabular}

\subsubsection{Disease and Diagnostic Biomarkers in Lung Cancer}

In a study by Dou and colleagues [222], differential expression of plasma sncRNAs between early-stage LUAD patients and healthy controls were examined. To bypass challenges with normalization, the researchers employed a pair-based strategy in which they compared the ratios of ncRNA pairs within the same sample. The researchers found and validated a panel of seven small ncRNA pair ratios that was able to discern LUAD patients from healthy controls (AUC $=100 \%$ in the training cohort, $89.5 \%$ in the validation cohort). Dou and colleagues also generated a secondary panel of five ncRNA pairs to distinguish LUAD patients from patients with benign disease (AUC $=82 \%$ in the training cohort, $74.2 \%$ in the validation cohort). Similarly, Zaporozhchenko and colleagues [223] found a panel of ten plasma miRNA pairs that differentiated lung cancer patients from non-cancer controls (AUC $=97.9 \%$ ). Lin and colleagues [224] examined plasma lncRNAs and found that a combination of SNHG1 and RMRP could distinguish NSCLC patients from controls with high sensitivity $(84 \%=$ development cohort, $82 \%=$ validation cohort $)$ and specificity $(87.5 \%=$ development cohort, $86 \%=$ validation cohort). However, the researchers encountered challenges with reliably detecting the expression of ncRNAs by qRT-PCR, which exemplifies the difficulties associated with quantifying circulating ncRNAs.

Distinct ncRNA signatures coming from tumor-derived exosomes have been identified as well. Jin and colleagues [225] found that a combination of exosomal let-7b-5p, let-7e-5p, miR-24-5p, and miR-21-5p was able to distinguish stage-I NSCLC patients from healthy controls (AUC $=89.9 \%$, sensitivity $=80.25 \%$, specificity $=92.31 \%$ ). Furthermore, they identified unique and shared exosomal miRNAs between LUAD and LUSC, where miR-181-5p and miR-361-5p were able to discern LUAD from other NSCLC patients (AUC $=93.6 \%$, sensitivity $=80.65 \%$, specificity $=91.67 \%$, and miR-320b and miR-10b-5p were able to discern LUSC from other NSCLC patients (AUC $=91.1 \%$, sensitivity $=83.33 \%$, specificity $=90.32 \%$ ). Similarly, Wang and colleagues [226] found that tissue circRNA0001073 and circRNA-0001495 could differentiate LUAD and LUSC subtypes. Within the 
exosomes, Grimolizzi and colleagues [227] also found that an elevation of miR-126, a tumor suppressor, could distinguish early-stage NSCLC patients from controls. They hypothesized that tumor cells upregulate the secretion of tumor-suppressive miR-126 for removal through the exosomal pathway. When miR-126-containing exosomes derived from normal endothelial cells were forcibly endocytosed, targeted lung cancer cells displayed reduced growth and angiogenesis. A recent study by Best and colleagues [228] also found that RNA profiles, including ncRNAs from tumor-educated platelets could accurately detect earlyand late-stage NSCLC. Specifically, through interacting with tumor cells, platelets sequester circulating tumor-associated biomolecules and, in response to external stimulation from the tumor environment, it can further undergo splicing of its pre-mRNA. The authors found that platelet RNA profiles are affected in nearly all cancers, including NSCLC, and that platelet RNA can supplement as an RNA onco-signature to tissue biomarkers such as KRAS mutations.

A-to-I editing of miRNAs is globally reduced in cancers [233]. Leveraging on this knowledge, edited miRNAs can serve as cancer biomarkers. Nigita and colleagues [229] analyzed edited miRNAs from small-RNA sequencing data of LUAD and LUSC tissues collected from the TCGA, and examined an independent cohort of plasma-derived exosomes from NSCLC patients. A significant downregulation of edited miR-411-5p was found in the exosomes of late-stage NSCLC patients compared to controls, which coordinated with reduced editing levels of miR-411-5p in NSCLC tissue samples from the TCGA. Maemura and colleagues [230] have also found significantly reduced miR-99a-5p editing from analyzing published small-RNA sequencing; this reduction was also observed in their cohort of 50 LUAD patient tissue samples.

\subsubsection{Prognostic and Treatment Biomarkers in Lung Cancer}

In addition to being markers of early disease, ncRNAs can further inform prognosis, disease progression, and treatment response of lung cancer patients. In the same study by Maemura and colleagues, they had also found that decreased miR-99a-5p editing was associated with lowered overall survival in patients [230]. Asakura and colleagues [231] found that a combination of plasma miR-1268b and miR-6075 showed high sensitivity (95\%) and specificity ( $99 \%)$ in predicting resectable lung cancer cases regardless of tumor histology and TNM staging. This study was particularly remarkable due to the large discovery (208 patients and healthy controls) and validation cohorts (1358 patients, 1970 healthy controls). Similarly, patients with decreased let-7 expression, independent of stage, have been observed to exhibit significantly worse prognosis after having undergone potentially curative tumor resection [176]. Notably, the prognostic value of let-7a for overall survival was found to be enhanced when examined in conjunction with elevated miR-155 [103]. Schmidt and colleagues [232] also found that positive expression of lncRNA MALAT1 in tumor tissue significantly correlated with poor prognosis for LUSC patients $(p=0.012)$.

\section{The Use of Non-Coding RNAs as Cancer Therapeutics}

As researchers unravel the diversity of RNAs, new strategies have been recognized for mimicking or antagonizing these nucleic acids [234]. Accordingly, the realm of RNAbased drugs has grown vastly and currently encompasses antisense oligonucleotides (ASOs), RNAi-based technologies (e.g., miRNAs and siRNAs), mRNA therapeutics, and single-guide RNAs (sgRNAs), with the latter being used to direct gene targeting of CRISPRCas9-based systems $[234,235]$. These therapeutic strategies can be designed to act on "nondruggable" targets where conventional therapeutics, which typically act at the protein-level, have previously failed $[235,236]$.

Curating RNA medicine for disease treatment has primarily employed two strategies with respect to ncRNAs. One approach is to restore tumor suppressive ncRNAs. For miRNAs, this can be accomplished through the delivery of synthetic analogs called "mimetics" [237]. The first mimetic to enter clinical trials for cancer treatment was MRX34, an analog of the tumor suppressor miR-34, which is frequently reduced in human can- 
cers $[35,45]$. MRX34 was delivered via a liposomal carrier to patients with advanced solid tumors $[45,238]$. Due to mixed treatment responses, along with several cases of adverse immunological reactions, the clinical trial has ceased for re-evaluation. It is possible that the delivery vehicle, rather than the drug, induced the immunological toxicity observed in some patients. Since MRX34, only one other mimetic has reached clinical trials: mesomiR16 , a miR-16 mimetic that is currently being evaluated for its efficacy in treating malignant pleural mesothelioma $[239,240]$.

The second approach aims to silence genes implicated in disease pathogenesis. This can be accomplished by utilizing our knowledge of intrinsic RNAi pathways to engineer exogenous siRNAs and artificial miRNAs (amiRNAs) that transiently repress target gene expression at the mRNA level [241-243]. Several siRNA-based therapeutic agents have reached clinical trials for cancer treatment, including ALN-VSP02, a lipid nanoparticlecontaining siRNAs against VEGF and KSP that is being tested on patients with advanced tumors who have at least one liver lesion [244]; Atu027, which is being used to treat advanced tumors and, more recently, pancreatic ductal cancer, through targeting PKN3 [245]; siG12D LODER, which delivers an siRNA against KRAS G12D for treating pancreatic cancer patients [246]; TKM-080301, which aims to reduce over-expressed PLK1 in patients with adrenocortical cancer [247]; and EPHARNA, a liposome-incorporated siRNA for EphA2 being used to treat patients with advanced solid tumors [248]. Furthermore, ASOs can be synthesized to target aberrantly expressed cancer-associated miRNAs and, to a lesser extent, lncRNAs. So-called "antagomirs" were demonstrated by Krützfeldt and colleagues [249] to be remarkably effective at silencing endogenous miRNAs, including miR-122. Currently, Miravirsen, a miR-122 antagonist, is being assessed for treatment of hepatitis C [250]. Regarding cancer treatment, Cobomarsen (MRG-106), an inhibitor of miR-155, is being evaluated for its ability to treat mycosis fungoides, a form of cutaneous T-cell lymphoma [251]. Current clinical trials implementing ncRNA-based therapeutics are in Table 3.

Table 3. Current clinical trials with ncRNA-based therapeutics.

\begin{tabular}{|c|c|c|c|}
\hline Clinical Trial ID & Stage & Disease & Therapeutic \\
\hline NCT03608631 & Phase I & Pancreatic cancer & $\begin{array}{l}\text { iExosomes derived mesenchymal stromal } \\
\text { cells with KRAS G12D siRNA }\end{array}$ \\
\hline NCT01591356 & Phase I & $\begin{array}{l}\text { Advanced or recurrent solid } \\
\text { tumors }\end{array}$ & $\begin{array}{l}\text { EphA2-targeting DOPC-encapsulated } \\
\text { siRNA }\end{array}$ \\
\hline NCT00938574 & Phase I & Advanced solid tumors & Atu027 (siRNA targeting PKN3) \\
\hline NCT00882180 + NCT01158079 & Phase I & $\begin{array}{l}\text { Advanced solid tumors with } \\
\text { liver involvement }\end{array}$ & $\begin{array}{l}\text { ALN-VSP02 (lipid nanoparticle with } \\
\text { siRNA targeting VEGF-A + KSP) }\end{array}$ \\
\hline NCT03087591 + NCT02166255 & Phase I & Metastatic solid neoplasms & $\begin{array}{l}\text { APN401 (peripheral blood mononuclear } \\
\text { cells transfected with cbl-b siRNA) }\end{array}$ \\
\hline NCT02369198 & Phase I & Pleural mesothelioma, NSCLC & TargomiRs (miR-16 mimic) \\
\hline NCT00689065 & Phase I (terminated) & Solid tumors & CALAA-01 (siRNA targeting RRM2) \\
\hline NCT01829971 + NCT02862145 & Phase I (terminated) & Solid tumors, liver cancer & MRX34 (miR-34 mimic) \\
\hline NCT01188785 + NCT01676259 & Phase I + II & Pancreatic cancer & $\begin{array}{l}\text { siG12D-LODER (siRNA targeting KRAS } \\
\text { G12D) }\end{array}$ \\
\hline NCT01437007 & Phase I/II & Primary/secondary liver cancer & TKM-080301 (siRNA targeting PLK1) \\
\hline NCT02110563 + NCT02314052 & Phase I/II (terminated) & $\begin{array}{l}\text { Solid tumor, multiple myeloma, } \\
\text { lymphoma }\end{array}$ & DCR-MYC (siRNA targeting MYC) \\
\hline NCT03713320 + NCT03837457 & Phase II (terminated) & $\begin{array}{l}\text { Cutaneous T-Cell } \\
\text { Lymphoma/Mycosis Fungoides }\end{array}$ & $\begin{array}{l}\text { Cobomarsen/MRG-106 (oligonucleotide } \\
\text { inhibitor of miR-155) }\end{array}$ \\
\hline
\end{tabular}

There are many aspects that are thoughtfully considered before these RNA drugs reach clinical trials. For example, to reduce the likelihood of off-target effects, designed molecules are subjected to in silico analyses (e.g., basic local alignment search tool (BLAST)) to evaluate its effect on gene expression [244]. Moreover, chemical modifications are often needed to increase the survivability of nucleic acids against circulating nucleases, and for negating immunological toxicity [244]. Such modifications include the addition of chemical groups at the $2^{\prime}$-position of ribose (e.g., 2'-O-methyl, 2'-O-methoxyethyl) and 
the substitution of nucleotides for locked nucleic acids [243,244,252]. A report by Cheng and colleagues [253] further showed that attachment of antagomirs to a peptide with a low $\mathrm{pH}$-induced transmembrane structure (pHLIP) can support the molecule within acidic tumor environments. Interestingly, Li and colleagues [254] found that delivery of siRNAs preassembled with Ago2 showed more potent and sustained gene silencing. However, cancer cells have been shown to evade delivered miRNA therapeutics by secreting the miRNAs complexed with Ago2 [255].

The selection of delivery method is also imperative for ensuring that the drug reaches its intended target rather than be eliminated via renal clearance [244]. Drug delivery can be non-targeted (e.g., nanoparticles) or targeted (e.g., conjugated to antibodies, ligands, aptamers) [243]. Furthermore, the drugs can be delivered regionally or systemically. Through either route, the molecules must overcome barriers of extravasation, transport within the interstitium, cellular internalization, and localization to appropriate cellular compartment for action [256]. Altogether, RNA medicine is an incredibly exciting development but, as with any drug design, it must circumvent challenges in toxicity, clearance, survivability, targeting, and cellular uptake [257].

\section{ncRNAs for the Treatment of Lung Cancer}

The benefits of implementing ncRNAs for lung cancer therapy have been assessed widely in preclinical models. Compared to siRNAs, miRNAs display imperfect complementarity to mRNAs such that it has the unique ability to affect multiple genes with fewer molecules required [242,258]. Acunzo and colleagues [243] developed amiRNAs for selectively targeting point mutations in KRAS deemed "non-druggable" in NSCLC. Taking advantage of the unique nature of the seed sequence of miRNAs, the researchers synthesized amiRNAs that demonstrate perfect binding to mutant KRAS G12S yet imperfect matching to KRAS WT. Compared with traditional siRNA-based drugs, the amiRNA-KD2 was able to discriminate KRAS G12S and WT lung cancer cells while retaining the ability to exert favorable effects on proliferation, migration, and necrosis. Furthermore, this strategy can be utilized to target other point mutations observed in cancer. The advantage of this type of drug design is that it minimizes toxicity against normal cells.

Vast studies have examined the effect of restoring tumor suppressor ncRNAs in preclinical lung cancer models. For instance, several groups have observed desirable effects from restoring miR-34 in reducing tumor burden in murine models of NSCLC [259-261], with similar efforts having been made to examine the effects of restoring other tumor suppressors such as miR-29 [262], let-7 [177], and MEG3 [190]. Some ncRNAs have been targeted in lung cancer treatment studies as well, including miR-21 [186] and MALAT1 [173]. Importantly, a variety of targeted delivery strategies have been rigorously evaluated by these research groups. Wu and colleagues [100] report success using cationic lipoplexes to deliver miR-29b to xenograft mice. Comparatively, Perepelyuk and colleagues [252] synthesized a hybridized nanoparticle with a MUC1-aptamer for targeting delivery of miR-29b to NSCLC cells expressing MUC1, a transmembrane protein that is aberrantly expressed by cancer cells. More broadly, new methodologies and systems are constantly being developed to study lung cancer and deliver therapeutic molecules. In a recent publication by Jeong and colleagues [263], they used human-cell derived exosomes for delivering miR-497 in vitro. In their study, the researchers created a model whereby A549 NSCLC cells were co-cultured with normal human endothelial cells (HUVEC) in a microfluidic device to better replicate the 3D tumor microenvironment.

As new discoveries within RNA medicine are made, pharmaceutical companies are continuing to lead clinical explorations and developments of RNA-based drugs [264]. Although no ncRNA-based drugs have been specifically curated for treating lung cancers, some of the aforementioned drugs have been utilized for treating advanced solid tumors including lung cancers. Furthermore, once the efficacy of varying RNA-based drugs in preclinical lung cancer models is determined, more RNA-based drugs can reach clinical trials. 


\section{Conclusions}

In the last several decades, the field of ncRNA research has experienced a noticeable surge in discoveries and innovations. There are numerous advantages to utilizing ncRNAs as biomarkers, including their relative stability and straightforward characterization by PCR. Traditionally, clinical trials for identifying cancer biomarkers aim to build panels of clinically informative ncRNAs without screening for more nuanced editing at the posttranscriptional level. By diversifying the screening process to encompass modified ncRNAs, this can help to strengthen the sensitivity and specificity of proposed biomarker panels. In addition to being potential biomarkers, these dysregulated ncRNAs can have functionally relevant roles in malignancies. For instance, several ncRNAs, such as MALAT1, miR-34, and the let7 family, have now been robustly linked to inducing cellular pathways that maintain the malignant phenotypes of lung cancers.

Furthermore, understanding the degree to which these ncRNAs are dysregulated have helped researchers to develop RNA-based therapeutics, such as mesomiR-16 and Cobomarsen, which aim to restore or suppress aberrantly expressed ncRNAs. Additionally, by leveraging on the RNAi activity of sncRNAs, synthetic siRNAs and amiRNAs can be utilized to target aberrantly mutated genes, such as KRAS, which are commonly observed in lung cancers. However, the inherent obstacles of achieving reproducibility, sensitivity, and specificity; building representative in vivo systems; tumor heterogeneity; biomarker normalization and protocol standardization; drug delivery; and drug-resistance pathways have generated challenges in translating these molecules from the bench to the bedside. In lung cancer, resistance to platinum-based chemotherapeutics can, in part, be explained through modulation of DNA repair pathways and cell cycle arrest by lncRNAs such as HOTAIR and MEG3. Overall, due to discussed challenges, potential RNA-based therapies curated for lung cancers have been mainly examined in preclinical mice models. However, although the challenges in quantification, detection, and delivery of ncRNAs have strained the rate at which these molecules can achieve clinical success, this field is still relatively young and has already deepened our understanding of lung cancer biology.

Author Contributions: P.L. contributed to drafting the manuscript and overall design. G.R., P.N.-S. and M.A. assisted with reviewing and editing the manuscript. All authors have read and agreed to the published version of the manuscript.

Funding: This work was supported by National Institutes of Health Grant NCI 5U01CA213330, CTSA award No. UL1TR002649 and NCATS 5KL2TR002648.

Conflicts of Interest: The authors declare no conflict of interest.

\section{References}

1. Deveson, I.W.; Hardwick, S.A.; Mercer, T.R.; Mattick, J.S. The Dimensions, Dynamics, and Relevance of the Mammalian Noncoding Transcriptome. Trends Genet. 2017, 33, 464-478. [CrossRef] [PubMed]

2. Mercer, T.R.; Gerhardt, D.J.; Dinger, M.E.; Crawford, J.; Trapnell, C.; Jeddeloh, J.A.; Mattick, J.S.; Rinn, J.L. Targeted RNA sequencing reveals the deep complexity of the human transcriptome. Nat. Biotechnol. 2011, 30, 99-104. [CrossRef]

3. Kapranov, P.; St Laurent, G. Dark Matter RNA: Existence, Function, and Controversy. Front. Genet. 2012, 3, 60. [CrossRef] [PubMed]

4. Lander, E.S.; Linton, L.M.; Birren, B.; Nusbaum, C.; Zody, M.C.; Baldwin, J.; Devon, K.; Dewar, K.; Doyle, M.; FitzHugh, W.; et al. Initial sequencing and analysis of the human genome. Nature 2001, 409, 860-921. [CrossRef] [PubMed]

5. Johnson, J.M.; Edwards, S.; Shoemaker, D.; Schadt, E.E. Dark matter in the genome: Evidence of widespread transcription detected by microarray tiling experiments. Trends Genet. 2005, 21, 93-102. [CrossRef] [PubMed]

6. Huttenhofer, A.; Schattner, P.; Polacek, N. Non-coding RNAs: Hope or hype? Trends Genet. 2005, 21, 289-297. [CrossRef]

7. Stark, R.; Grzelak, M.; Hadfield, J. RNA sequencing: The teenage years. Nat. Rev. Genet. 2019, 20, 631-656. [CrossRef]

8. Kowalczyk, M.S.; Higgs, D.R.; Gingeras, T.R. Molecular biology: RNA discrimination. Nature 2012, 482, 310-311. [CrossRef]

9. Hoagland, M.B.; Stephenson, M.L.; Scott, J.F.; Hecht, L.I.; Zamecnik, P.C. A soluble ribonucleic acid intermediate in protein synthesis. J. Biol. Chem. 1958, 231, 241-257. [CrossRef]

10. Hsu, M.T.; Coca-Prados, M. Electron microscopic evidence for the circular form of RNA in the cytoplasm of eukaryotic cells. Nature 1979, 280, 339-340. [CrossRef] 
11. Pachnis, V.; Belayew, A.; Tilghman, S.M. Locus unlinked to alpha-fetoprotein under the control of the murine raf and Rif genes. Proc. Natl. Acad. Sci. USA 1984, 81, 5523-5527. [CrossRef]

12. Lee, R.C.; Feinbaum, R.L.; Ambros, V. The, C. elegans heterochronic gene lin-4 encodes small RNAs with antisense complementarity to lin-14. Cell 1993, 75, 843-854. [CrossRef]

13. Wightman, B.; Ha, I.; Ruvkun, G. Posttranscriptional regulation of the heterochronic gene lin-14 by lin-4 mediates temporal pattern formation in C. elegans. Cell 1993, 75, 855-862. [CrossRef]

14. Lagos-Quintana, M.; Rauhut, R.; Lendeckel, W.; Tuschl, T. Identification of novel genes coding for small expressed RNAs. Science 2001, 294, 853-858. [CrossRef]

15. Fire, A.; Xu, S.; Montgomery, M.K.; Kostas, S.A.; Driver, S.E.; Mello, C.C. Potent and specific genetic interference by doublestranded RNA in Caenorhabditis elegans. Nature 1998, 391, 806-811. [CrossRef] [PubMed]

16. Hamilton, A.J.; Baulcombe, D.C. A species of small antisense RNA in posttranscriptional gene silencing in plants. Science 1999, 286, 950-952. [CrossRef]

17. Bernstein, E.; Caudy, A.A.; Hammond, S.M.; Hannon, G.J. Role for a bidentate ribonuclease in the initiation step of RNA interference. Nature 2001, 409, 363-366. [CrossRef] [PubMed]

18. Hutvagner, G.; McLachlan, J.; Pasquinelli, A.E.; Balint, E.; Tuschl, T.; Zamore, P.D. A cellular function for the RNA-interference enzyme Dicer in the maturation of the let-7 small temporal RNA. Science 2001, 293, 834-838. [CrossRef]

19. Billy, E.; Brondani, V.; Zhang, H.; Muller, U.; Filipowicz, W. Specific interference with gene expression induced by long, doublestranded RNA in mouse embryonal teratocarcinoma cell lines. Proc. Natl. Acad. Sci. USA 2001, 98, 14428-14433. [CrossRef]

20. Kapranov, P.; Cawley, S.E.; Drenkow, J.; Bekiranov, S.; Strausberg, R.L.; Fodor, S.P.; Gingeras, T.R. Large-scale transcriptional activity in chromosomes 21 and 22. Science 2002, 296, 916-919. [CrossRef]

21. Rinn, J.L.; Euskirchen, G.; Bertone, P.; Martone, R.; Luscombe, N.M.; Hartman, S.; Harrison, P.M.; Nelson, F.K.; Miller, P.; Gerstein, M.; et al. The transcriptional activity of human Chromosome 22. Genes Dev. 2003, 17, 529-540. [CrossRef] [PubMed]

22. Calin, G.A.; Dumitru, C.D.; Shimizu, M.; Bichi, R.; Zupo, S.; Noch, E.; Aldler, H.; Rattan, S.; Keating, M.; Rai, K.; et al. Frequent deletions and down-regulation of micro- RNA genes miR15 and miR16 at 13q14 in chronic lymphocytic leukemia. Proc. Natl. Acad. Sci. USA 2002, 99, 15524-15529. [CrossRef] [PubMed]

23. Lee, Y.; Ahn, C.; Han, J.; Choi, H.; Kim, J.; Yim, J.; Lee, J.; Provost, P.; Radmark, O.; Kim, S.; et al. The nuclear RNase III Drosha initiates microRNA processing. Nature 2003, 425, 415-419. [CrossRef]

24. Margulies, M.; Egholm, M.; Altman, W.E.; Attiya, S.; Bader, J.S.; Bemben, L.A.; Berka, J.; Braverman, M.S.; Chen, Y.J.; Chen, Z.; et al. Genome sequencing in microfabricated high-density picolitre reactors. Nature 2005, 437, 376-380. [CrossRef]

25. Aravin, A.; Gaidatzis, D.; Pfeffer, S.; Lagos-Quintana, M.; Landgraf, P.; Iovino, N.; Morris, P.; Brownstein, M.J.; KuramochiMiyagawa, S.; Nakano, T.; et al. A novel class of small RNAs bind to MILI protein in mouse testes. Nature 2006, 442, $203-207$. [CrossRef] [PubMed]

26. Girard, A.; Sachidanandam, R.; Hannon, G.J.; Carmell, M.A. A germline-specific class of small RNAs binds mammalian Piwi proteins. Nature 2006, 442, 199-202. [CrossRef] [PubMed]

27. Grivna, S.T.; Beyret, E.; Wang, Z.; Lin, H. A novel class of small RNAs in mouse spermatogenic cells. Genes Dev. 2006, 20, 1709-1714. [CrossRef] [PubMed]

28. Watanabe, T.; Takeda, A.; Tsukiyama, T.; Mise, K.; Okuno, T.; Sasaki, H.; Minami, N.; Imai, H. Identification and characterization of two novel classes of small RNAs in the mouse germline: Retrotransposon-derived siRNAs in oocytes and germline small RNAs in testes. Genes Dev. 2006, 20, 1732-1743. [CrossRef]

29. Bainbridge, M.N.; Warren, R.L.; Hirst, M.; Romanuik, T.; Zeng, T.; Go, A.; Delaney, A.; Griffith, M.; Hickenbotham, M.; Magrini, V.; et al. Analysis of the prostate cancer cell line LNCaP transcriptome using a sequencing-by-synthesis approach. BMC Genom. 2006, 7, 246. [CrossRef] [PubMed]

30. Cheung, F.; Haas, B.J.; Goldberg, S.M.; May, G.D.; Xiao, Y.; Town, C.D. Sequencing Medicago truncatula expressed sequenced tags using 454 Life Sciences technology. BMC Genom. 2006, 7, 272. [CrossRef]

31. Lister, R.; O’Malley, R.C.; Tonti-Filippini, J.; Gregory, B.D.; Berry, C.C.; Millar, A.H.; Ecker, J.R. Highly integrated single-base resolution maps of the epigenome in Arabidopsis. Cell 2008, 133, 523-536. [CrossRef] [PubMed]

32. Emrich, S.J.; Barbazuk, W.B.; Li, L.; Schnable, P.S. Gene discovery and annotation using LCM-454 transcriptome sequencing. Genome Res. 2007, 17, 69-73. [CrossRef] [PubMed]

33. Weber, A.P.; Weber, K.L.; Carr, K.; Wilkerson, C.; Ohlrogge, J.B. Sampling the Arabidopsis transcriptome with massively parallel pyrosequencing. Plant Physiol. 2007, 144, 32-42. [CrossRef]

34. Djebali, S.; Davis, C.A.; Merkel, A.; Dobin, A.; Lassmann, T.; Mortazavi, A.; Tanzer, A.; Lagarde, J.; Lin, W.; Schlesinger, F.; et al. Landscape of transcription in human cells. Nature 2012, 489, 101-108. [CrossRef] [PubMed]

35. Bouchie, A. First microRNA mimic enters clinic. Nat. Biotechnol. 2013, 31, 577. [CrossRef] [PubMed]

36. Sun, M.; Kraus, W.L. From discovery to function: The expanding roles of long noncoding RNAs in physiology and disease. Endocr. Rev. 2015, 36, 25-64. [CrossRef] [PubMed]

37. Kashi, K.; Henderson, L.; Bonetti, A.; Carninci, P. Discovery and functional analysis of lncRNAs: Methodologies to investigate an uncharacterized transcriptome. Biochim. Biophys. Acta 2016, 1859, 3-15. [CrossRef] [PubMed]

38. Luo, M.L. Methods to Study Long Noncoding RNA Biology in Cancer. Adv. Exp. Med. Biol. 2016, 927, 69-107. [CrossRef] 
39. Choudhari, R.; Sedano, M.J.; Harrison, A.L.; Subramani, R.; Lin, K.Y.; Ramos, E.I.; Lakshmanaswamy, R.; Gadad, S.S. Long noncoding RNAs in cancer: From discovery to therapeutic targets. Adv. Clin. Chem. 2020, 95, 105-147. [CrossRef] [PubMed]

40. Zhang, P.; Wu, W.; Chen, Q.; Chen, M. Non-Coding RNAs and their Integrated Networks. J. Integr. Bioinform. 2019, 16. [CrossRef]

41. Cech, T.R.; Steitz, J.A. The noncoding RNA revolution-trashing old rules to forge new ones. Cell 2014, 157, 77-94. [CrossRef]

42. Liang, J.; Wen, J.; Huang, Z.; Chen, X.P.; Zhang, B.X.; Chu, L. Small Nucleolar RNAs: Insight Into Their Function in Cancer. Front. Oncol. 2019, 9, 587. [CrossRef] [PubMed]

43. Kim, V.N. Small RNAs just got bigger: Piwi-interacting RNAs (piRNAs) in mammalian testes. Genes Dev. 2006, 20 , 1993-1997. [CrossRef]

44. Kim, V.N.; Han, J.; Siomi, M.C. Biogenesis of small RNAs in animals. Nat. Rev. Mol. Cell Biol. 2009, 10, 126-139. [CrossRef]

45. Ling, H.; Fabbri, M.; Calin, G.A. MicroRNAs and other non-coding RNAs as targets for anticancer drug development. Nat. Rev. Drug Discov. 2013, 12, 847-865. [CrossRef] [PubMed]

46. Carthew, R.W.; Sontheimer, E.J. Origins and Mechanisms of miRNAs and siRNAs. Cell 2009, 136, 642-655. [CrossRef]

47. Siomi, M.C.; Sato, K.; Pezic, D.; Aravin, A.A. PIWI-interacting small RNAs: The vanguard of genome defence. Nat. Rev. Mol. Cell Biol. 2011, 12, 246-258. [CrossRef]

48. Moyano, M.; Stefani, G. piRNA involvement in genome stability and human cancer. J. Hematol. Oncol. 2015, 8, 38. [CrossRef]

49. Kapranov, P.; Cheng, J.; Dike, S.; Nix, D.A.; Duttagupta, R.; Willingham, A.T.; Stadler, P.F.; Hertel, J.; Hackermuller, J.; Hofacker, I.L.; et al. RNA maps reveal new RNA classes and a possible function for pervasive transcription. Science 2007, 316, 1484-1488. [CrossRef] [PubMed]

50. Jiang, S.; Cheng, S.J.; Ren, L.C.; Wang, Q.; Kang, Y.J.; Ding, Y.; Hou, M.; Yang, X.X.; Lin, Y.; Liang, N.; et al. An expanded landscape of human long noncoding RNA. Nucleic Acids Res. 2019, 47, 7842-7856. [CrossRef] [PubMed]

51. St Laurent, G.; Wahlestedt, C.; Kapranov, P. The Landscape of long noncoding RNA classification. Trends Genet. 2015, 31, $239-251$. [CrossRef] [PubMed]

52. Ransohoff, J.D.; Wei, Y.; Khavari, P.A. The functions and unique features of long intergenic non-coding RNA. Nat. Rev. Mol. Cell Biol. 2018, 19, 143-157. [CrossRef]

53. Chen, L.L. The expanding regulatory mechanisms and cellular functions of circular RNAs. Nat. Rev. Mol. Cell Biol. 2020, 21, 475-490. [CrossRef]

54. Balakirev, E.S.; Ayala, F.J. Pseudogenes: Are they “junk” or functional DNA? Annu. Rev. Genet. 2003, 37, 123-151. [CrossRef]

55. Slack, F.J.; Chinnaiyan, A.M. The Role of Non-coding RNAs in Oncology. Cell 2019, 179, 1033-1055. [CrossRef] [PubMed]

56. Hanahan, D.; Weinberg, R.A. Hallmarks of cancer: The next generation. Cell 2011, 144, 646-674. [CrossRef] [PubMed]

57. Hanahan, D.; Weinberg, R.A. The hallmarks of cancer. Cell 2000, 100, 57-70. [CrossRef]

58. Ling, H.; Girnita, L.; Buda, O.; Calin, G.A. Non-coding RNAs: The cancer genome dark matter that matters! Clin. Chem. Lab. Med. 2017, 55, 705-714. [CrossRef] [PubMed]

59. Calin, G.A.; Croce, C.M. MicroRNA signatures in human cancers. Nat. Rev. Cancer 2006, 6, 857-866. [CrossRef] [PubMed]

60. Salmena, L.; Poliseno, L.; Tay, Y.; Kats, L.; Pandolfi, P.P. A ceRNA hypothesis: The Rosetta Stone of a hidden RNA language? Cell 2011, 146, 353-358. [CrossRef]

61. Wang, Y.; Lee, C.G. MicroRNA and cancer-Focus on apoptosis. J. Cell. Mol. Med. 2009, 13, 12-23. [CrossRef] [PubMed]

62. Hayes, J.; Peruzzi, P.P.; Lawler, S. MicroRNAs in cancer: Biomarkers, functions and therapy. Trends Mol. Med. 2014, 20, 460-469. [CrossRef]

63. Krek, A.; Grun, D.; Poy, M.N.; Wolf, R.; Rosenberg, L.; Epstein, E.J.; MacMenamin, P.; da Piedade, I.; Gunsalus, K.C.; Stoffel, M.; et al. Combinatorial microRNA target predictions. Nat. Genet. 2005, 37, 495-500. [CrossRef] [PubMed]

64. Fabbri, M.; Paone, A.; Calore, F.; Galli, R.; Gaudio, E.; Santhanam, R.; Lovat, F.; Fadda, P.; Mao, C.; Nuovo, G.J.; et al. MicroRNAs bind to Toll-like receptors to induce prometastatic inflammatory response. Proc. Natl. Acad. Sci. USA 2012, 109, E2110-E2116. [CrossRef] [PubMed]

65. Fabbri, M.; Paone, A.; Calore, F.; Galli, R.; Croce, C.M. A new role for microRNAs, as ligands of Toll-like receptors. RNA Biol. 2013, 10, 169-174. [CrossRef] [PubMed]

66. Qiao, D.; Zeeman, A.M.; Deng, W.; Looijenga, L.H.; Lin, H. Molecular characterization of hiwi, a human member of the piwi gene family whose overexpression is correlated to seminomas. Oncogene 2002, 21, 3988-3999. [CrossRef]

67. Zhao, Y.M.; Zhou, J.M.; Wang, L.R.; He, H.W.; Wang, X.L.; Tao, Z.H.; Sun, H.C.; Wu, W.Z.; Fan, J.; Tang, Z.Y.; et al. HIWI is associated with prognosis in patients with hepatocellular carcinoma after curative resection. Cancer 2012, 118, $2708-2717$. [CrossRef]

68. Esquela-Kerscher, A.; Slack, F.J. Oncomirs-Micrornas with a role in cancer. Nat. Rev. Cancer 2006, 6, 259-269. [CrossRef]

69. Svoronos, A.A.; Engelman, D.M.; Slack, F.J. OncomiR or Tumor Suppressor? The Duplicity of MicroRNAs in Cancer. Cancer Res. 2016, 76, 3666-3670. [CrossRef]

70. Hajjari, M.; Salavaty, A. HOTAIR: An oncogenic long non-coding RNA in different cancers. Cancer Biol. Med. 2015, 12, 1-9. [CrossRef] [PubMed]

71. Klinge, C.M. Non-coding RNAs: Long non-coding RNAs and microRNAs in endocrine-related cancers. Endocr. Relat. Cancer 2018, 25, R259-R282. [CrossRef] [PubMed] 
72. Rinn, J.L.; Kertesz, M.; Wang, J.K.; Squazzo, S.L.; Xu, X.; Brugmann, S.A.; Goodnough, L.H.; Helms, J.A.; Farnham, P.J.; Segal, E.; et al. Functional demarcation of active and silent chromatin domains in human HOX loci by noncoding RNAs. Cell 2007, 129, 1311-1323. [CrossRef] [PubMed]

73. Tripathi, V.; Ellis, J.D.; Shen, Z.; Song, D.Y.; Pan, Q.; Watt, A.T.; Freier, S.M.; Bennett, C.F.; Sharma, A.; Bubulya, P.A.; et al. The nuclear-retained noncoding RNA MALAT1 regulates alternative splicing by modulating SR splicing factor phosphorylation. Mol. Cell 2010, 39, 925-938. [CrossRef] [PubMed]

74. Engreitz, J.M.; Sirokman, K.; McDonel, P.; Shishkin, A.A.; Surka, C.; Russell, P.; Grossman, S.R.; Chow, A.Y.; Guttman, M.; Lander, E.S. RNA-RNA interactions enable specific targeting of noncoding RNAs to nascent Pre-mRNAs and chromatin sites. Cell 2014, 159, 188-199. [CrossRef] [PubMed]

75. Zhou, Y.; Zhong, Y.; Wang, Y.; Zhang, X.; Batista, D.L.; Gejman, R.; Ansell, P.J.; Zhao, J.; Weng, C.; Klibanski, A. Activation of p53 by MEG3 non-coding RNA. J. Biol. Chem. 2007, 282, 24731-24742. [CrossRef] [PubMed]

76. Al-Rugeebah, A.; Alanazi, M.; Parine, N.R. MEG3: An Oncogenic Long Non-coding RNA in Different Cancers. Pathol. Oncol. Res. 2019, 25, 859-874. [CrossRef]

77. Raveh, E.; Matouk, I.J.; Gilon, M.; Hochberg, A. The H19 Long non-coding RNA in cancer initiation, progression and metastasisA proposed unifying theory. Mol. Cancer 2015, 14, 184. [CrossRef]

78. Karreth, F.A.; Reschke, M.; Ruocco, A.; Ng, C.; Chapuy, B.; Leopold, V.; Sjoberg, M.; Keane, T.M.; Verma, A.; Ala, U.; et al. The BRAF pseudogene functions as a competitive endogenous RNA and induces lymphoma in vivo. Cell 2015, 161, 319-332. [CrossRef]

79. Jeter, C.R.; Yang, T.; Wang, J.; Chao, H.P.; Tang, D.G. Concise Review: NANOG in Cancer Stem Cells and Tumor Development: An Update and Outstanding Questions. Stem Cells 2015, 33, 2381-2390. [CrossRef]

80. Villodre, E.S.; Kipper, F.C.; Pereira, M.B.; Lenz, G. Roles of OCT4 in tumorigenesis, cancer therapy resistance and prognosis. Cancer Treat. Rev. 2016, 51, 1-9. [CrossRef] [PubMed]

81. Johnsson, P.; Ackley, A.; Vidarsdottir, L.; Lui, W.O.; Corcoran, M.; Grander, D.; Morris, K.V. A pseudogene long-noncoding-RNA network regulates PTEN transcription and translation in human cells. Nat. Struct. Mol. Biol. 2013, 20, 440-446. [CrossRef]

82. Li, R.K.; Gao, J.; Guo, L.H.; Huang, G.Q.; Luo, W.H. PTENP1 acts as a ceRNA to regulate PTEN by sponging miR-19b and explores the biological role of PTENP1 in breast cancer. Cancer Gene Ther. 2017, 24, 309-315. [CrossRef]

83. Guo, X.; Deng, L.; Deng, K.; Wang, H.; Shan, T.; Zhou, H.; Liang, Z.; Xia, J.; Li, C. Pseudogene PTENP1 Suppresses Gastric Cancer Progression by Modulating PTEN. Anticancer Agents Med. Chem. 2016, 16, 456-464. [CrossRef] [PubMed]

84. Yu, G.; Yao, W.; Gumireddy, K.; Li, A.; Wang, J.; Xiao, W.; Chen, K.; Xiao, H.; Li, H.; Tang, K.; et al. Pseudogene PTENP1 functions as a competing endogenous RNA to suppress clear-cell renal cell carcinoma progression. Mol. Cancer Ther. 2014, 13, 3086-3097. [CrossRef]

85. Qiu, M.; Xia, W.; Chen, R.; Wang, S.; Xu, Y.; Ma, Z.; Xu, W.; Zhang, E.; Wang, J.; Fang, T.; et al. The Circular RNA circPRKCI Promotes Tumor Growth in Lung Adenocarcinoma. Cancer Res. 2018, 78, 2839-2851. [CrossRef] [PubMed]

86. Zhang, X.; Yang, H.; Zhao, L.; Li, G.; Duan, Y. Circular RNA PRKCI promotes glioma cell progression by inhibiting microRNA-545. Cell Death Dis. 2019, 10, 616. [CrossRef]

87. Zeng, K.; Chen, X.; Xu, M.; Liu, X.; Hu, X.; Xu, T.; Sun, H.; Pan, Y.; He, B.; Wang, S. CircHIPK3 promotes colorectal cancer growth and metastasis by sponging miR-7. Cell Death Dis. 2018, 9, 417. [CrossRef] [PubMed]

88. Chen, Z.G.; Zhao, H.J.; Lin, L.; Liu, J.B.; Bai, J.Z.; Wang, G.S. Circular RNA CirCHIPK3 promotes cell proliferation and invasion of breast cancer by sponging miR-193a/HMGB1/PI3K/AKT axis. Thorac. Cancer 2020, 11, 2660-2671. [CrossRef]

89. Li, D.; Luo, Y.; Gao, Y.; Yang, Y.; Wang, Y.; Xu, Y.; Tan, S.; Zhang, Y.; Duan, J.; Yang, Y. piR-651 promotes tumor formation in non-small cell lung carcinoma through the upregulation of cyclin D1 and CDK4. Int. J. Mol. Med. 2016, 38, 927-936. [CrossRef]

90. Cheng, J.; Deng, H.; Xiao, B.; Zhou, H.; Zhou, F.; Shen, Z.; Guo, J. piR-823, a novel non-coding small RNA, demonstrates in vitro and in vivo tumor suppressive activity in human gastric cancer cells. Cancer Lett. 2012, 315, 12-17. [CrossRef]

91. Su, J.F.; Zhao, F.; Gao, Z.W.; Hou, Y.J.; Li, Y.Y.; Duan, L.J.; Lun, S.M.; Yang, H.J.; Li, J.K.; Dai, N.T.; et al. piR-823 demonstrates tumor oncogenic activity in esophageal squamous cell carcinoma through DNA methylation induction via DNA methyltransferase 3B Pathol. Res. Pract. 2020, 216, 152848. [CrossRef]

92. Yin, J.; Jiang, X.Y.; Qi, W.; Ji, C.G.; Xie, X.L.; Zhang, D.X.; Cui, Z.J.; Wang, C.K.; Bai, Y.; Wang, J.; et al. piR-823 contributes to colorectal tumorigenesis by enhancing the transcriptional activity of HSF1. Cancer Sci. 2017, 108, 1746-1756. [CrossRef] [PubMed]

93. Zhang, H.; Ren, Y.; Xu, H.; Pang, D.; Duan, C.; Liu, C. The expression of stem cell protein Piwil2 and piR-932 in breast cancer. Surg. Oncol. 2013, 22, 217-223. [CrossRef] [PubMed]

94. Cimmino, A.; Calin, G.A.; Fabbri, M.; Iorio, M.V.; Ferracin, M.; Shimizu, M.; Wojcik, S.E.; Aqeilan, R.I.; Zupo, S.; Dono, M.; et al. miR-15 and miR-16 induce apoptosis by targeting BCL2. Proc. Natl. Acad. Sci. USA 2005, 102, 13944-13949. [CrossRef] [PubMed]

95. Calin, G.A.; Cimmino, A.; Fabbri, M.; Ferracin, M.; Wojcik, S.E.; Shimizu, M.; Taccioli, C.; Zanesi, N.; Garzon, R.; Aqeilan, R.I.; et al. MiR-15a and miR-16-1 cluster functions in human leukemia. Proc. Natl. Acad. Sci. USA 2008, 105, 5166-5171. [CrossRef]

96. Xue, G.; Yan, H.L.; Zhang, Y.; Hao, L.Q.; Zhu, X.T.; Mei, Q.; Sun, S.H. c-Myc-mediated repression of miR-15-16 in hypoxia is induced by increased HIF-2alpha and promotes tumor angiogenesis and metastasis by upregulating FGF2. Oncogene 2015, 34, 1393-1406. [CrossRef] [PubMed] 
97. Bonci, D.; Coppola, V.; Musumeci, M.; Addario, A.; Giuffrida, R.; Memeo, L.; D’Urso, L.; Pagliuca, A.; Biffoni, M.; Labbaye, C.; et al. The miR-15a-miR-16-1 cluster controls prostate cancer by targeting multiple oncogenic activities. Nat. Med. 2008, 14, 1271-1277. [CrossRef]

98. Mott, J.L.; Kobayashi, S.; Bronk, S.F.; Gores, G.J. mir-29 regulates Mcl-1 protein expression and apoptosis. Oncogene 2007, 26, 6133-6140. [CrossRef]

99. Park, S.Y.; Lee, J.H.; Ha, M.; Nam, J.W.; Kim, V.N. miR-29 miRNAs activate p53 by targeting p85 alpha and CDC42. Nat. Struct. Mol. Biol. 2009, 16, 23-29. [CrossRef]

100. Wu, Y.; Crawford, M.; Mao, Y.; Lee, R.J.; Davis, I.C.; Elton, T.S.; Lee, L.J.; Nana-Sinkam, S.P. Therapeutic Delivery of MicroRNA-29b by Cationic Lipoplexes for Lung Cancer. Mol. Ther. Nucleic Acids 2013, 2, e84. [CrossRef] [PubMed]

101. Muluhngwi, P.; Alizadeh-Rad, N.; Vittitow, S.L.; Kalbfleisch, T.S.; Klinge, C.M. The miR-29 transcriptome in endocrine-sensitive and resistant breast cancer cells. Sci. Rep. 2017, 7, 5205. [CrossRef]

102. Ru, P.; Steele, R.; Newhall, P.; Phillips, N.J.; Toth, K.; Ray, R.B. miRNA-29b suppresses prostate cancer metastasis by regulating epithelial-mesenchymal transition signaling. Mol. Cancer Ther. 2012, 11, 1166-1173. [CrossRef] [PubMed]

103. Yanaihara, N.; Caplen, N.; Bowman, E.; Seike, M.; Kumamoto, K.; Yi, M.; Stephens, R.M.; Okamoto, A.; Yokota, J.; Tanaka, T.; et al. Unique microRNA molecular profiles in lung cancer diagnosis and prognosis. Cancer Cell 2006, 9, 189-198. [CrossRef]

104. Baradaran, B.; Shahbazi, R.; Khordadmehr, M. Dysregulation of key microRNAs in pancreatic cancer development. Biomed. Pharmacother. 2019, 109, 1008-1015. [CrossRef] [PubMed]

105. Kwon, J.J.; Factora, T.D.; Dey, S.; Kota, J. A Systematic Review of miR-29 in Cancer. Mol. Ther. Oncolytics 2019, 12, 173-194. [CrossRef]

106. He, L.; He, X.; Lim, L.P.; de Stanchina, E.; Xuan, Z.; Liang, Y.; Xue, W.; Zender, L.; Magnus, J.; Ridzon, D.; et al. A microRNA component of the p53 tumour suppressor network. Nature 2007, 447, 1130-1134. [CrossRef]

107. Bommer, G.T.; Gerin, I.; Feng, Y.; Kaczorowski, A.J.; Kuick, R.; Love, R.E.; Zhai, Y.; Giordano, T.J.; Qin, Z.S.; Moore, B.B.; et al. p53-mediated activation of miRNA34 candidate tumor-suppressor genes. Curr. Biol. 2007, 17, 1298-1307. [CrossRef]

108. Raver-Shapira, N.; Marciano, E.; Meiri, E.; Spector, Y.; Rosenfeld, N.; Moskovits, N.; Bentwich, Z.; Oren, M. Transcriptional activation of miR-34a contributes to p53-mediated apoptosis. Mol. Cell 2007, 26, 731-743. [CrossRef]

109. Rokavec, M.; Li, H.; Jiang, L.; Hermeking, H. The p53/miR-34 axis in development and disease. J. Mol. Cell Biol. 2014, 6, 214-230. [CrossRef] [PubMed]

110. O'Day, E.; Lal, A. MicroRNAs and their target gene networks in breast cancer. Breast Cancer Res. 2010, 12, 201. [CrossRef]

111. Misso, G.; Di Martino, M.T.; De Rosa, G.; Farooqi, A.A.; Lombardi, A.; Campani, V.; Zarone, M.R.; Gulla, A.; Tagliaferri, P.; Tassone, P.; et al. Mir-34: A new weapon against cancer? Mol. Ther. Nucleic Acids 2014, 3, e194. [CrossRef] [PubMed]

112. Gregory, P.A.; Bert, A.G.; Paterson, E.L.; Barry, S.C.; Tsykin, A.; Farshid, G.; Vadas, M.A.; Khew-Goodall, Y.; Goodall, G.J. The miR-200 family and miR-205 regulate epithelial to mesenchymal transition by targeting ZEB1 and SIP1. Nat. Cell Biol. 2008, 10, 593-601. [CrossRef]

113. Chirshev, E.; Oberg, K.C.; Ioffe, Y.J.; Unternaehrer, J.J. Let-7 as biomarker, prognostic indicator, and therapy for precision medicine in cancer. Clin. Transl. Med. 2019, 8, 24. [CrossRef]

114. Bautista-Sanchez, D.; Arriaga-Canon, C.; Pedroza-Torres, A.; De La Rosa-Velazquez, I.A.; Gonzalez-Barrios, R.; ContrerasEspinosa, L.; Montiel-Manriquez, R.; Castro-Hernandez, C.; Fragoso-Ontiveros, V.; Alvarez-Gomez, R.M.; et al. The Promising Role of miR-21 as a Cancer Biomarker and Its Importance in RNA-Based Therapeutics. Mol. Ther. Nucleic Acids 2020, 20, 409-420. [CrossRef] [PubMed]

115. Higgs, G.; Slack, F. The multiple roles of microRNA-155 in oncogenesis. J. Clin. Bioinforma. 2013, 3, 17. [CrossRef] [PubMed]

116. He, L.; Thomson, J.M.; Hemann, M.T.; Hernando-Monge, E.; Mu, D.; Goodson, S.; Powers, S.; Cordon-Cardo, C.; Lowe, S.W.; Hannon, G.J.; et al. A microRNA polycistron as a potential human oncogene. Nature 2005, 435, 828-833. [CrossRef] [PubMed]

117. Mogilyansky, E.; Rigoutsos, I. The miR-17/92 cluster: A comprehensive update on its genomics, genetics, functions and increasingly important and numerous roles in health and disease. Cell Death Differ. 2013, 20, 1603-1614. [CrossRef] [PubMed]

118. Brase, J.C.; Wuttig, D.; Kuner, R.; Sultmann, H. Serum microRNAs as non-invasive biomarkers for cancer. Mol. Cancer 2010, 9, 306. [CrossRef]

119. Garofalo, M.; Quintavalle, C.; Romano, G.; Croce, C.M.; Condorelli, G. miR221/222 in cancer: Their role in tumor progression and response to therapy. Curr. Mol. Med. 2012, 12, 27-33. [CrossRef]

120. Calin, G.A.; Croce, C.M. MicroRNAs and chromosomal abnormalities in cancer cells. Oncogene 2006, 25, 6202-6210. [CrossRef]

121. Chang, T.C.; Yu, D.; Lee, Y.S.; Wentzel, E.A.; Arking, D.E.; West, K.M.; Dang, C.V.; Thomas-Tikhonenko, A.; Mendell, J.T. Widespread microRNA repression by Myc contributes to tumorigenesis. Nat. Genet. 2008, 40, 43-50. [CrossRef] [PubMed]

122. Kumar, M.S.; Lu, J.; Mercer, K.L.; Golub, T.R.; Jacks, T. Impaired microRNA processing enhances cellular transformation and tumorigenesis. Nat. Genet. 2007, 39, 673-677. [CrossRef] [PubMed]

123. Lu, J.; Getz, G.; Miska, E.A.; Alvarez-Saavedra, E.; Lamb, J.; Peck, D.; Sweet-Cordero, A.; Ebert, B.L.; Mak, R.H.; Ferrando, A.A.; et al. MicroRNA expression profiles classify human cancers. Nature 2005, 435, 834-838. [CrossRef] [PubMed]

124. Lin, S.; Gregory, R.I. MicroRNA biogenesis pathways in cancer. Nat. Rev. Cancer 2015, 15, 321-333. [CrossRef] [PubMed]

125. Feng, J.; Chen, K.; Dong, X.; Xu, X.; Jin, Y.; Zhang, X.; Chen, W.; Han, Y.; Shao, L.; Gao, Y.; et al. Genome-wide identification of cancer-specific alternative splicing in circRNA. Mol. Cancer 2019, 18, 35. [CrossRef] [PubMed] 
126. Benne, R.; Van den Burg, J.; Brakenhoff, J.P.; Sloof, P.; Van Boom, J.H.; Tromp, M.C. Major transcript of the frameshifted coxII gene from trypanosome mitochondria contains four nucleotides that are not encoded in the DNA. Cell 1986, 46, 819-826. [CrossRef]

127. Romano, G.; Saviana, M.; Le, P.; Li, H.; Micalo, L.; Nigita, G.; Acunzo, M.; Nana-Sinkam, P. Non-Coding RNA Editing in Cancer Pathogenesis. Cancers 2020, 12, 1845. [CrossRef]

128. Romano, G.; Veneziano, D.; Nigita, G.; Nana-Sinkam, S.P. RNA Methylation in ncRNA: Classes, Detection, and Molecular Associations. Front. Genet. 2018, 9, 243. [CrossRef]

129. Scott, G.K.; Mattie, M.D.; Berger, C.E.; Benz, S.C.; Benz, C.C. Rapid alteration of microRNA levels by histone deacetylase inhibition. Cancer Res. 2006, 66, 1277-1281. [CrossRef]

130. Lopez-Urrutia, E.; Bustamante Montes, L.P.; Ladron de Guevara Cervantes, D.; Perez-Plasencia, C.; Campos-Parra, A.D. Crosstalk Between Long Non-coding RNAs, Micro-RNAs and mRNAs: Deciphering Molecular Mechanisms of Master Regulators in Cancer. Front. Oncol. 2019, 9, 669. [CrossRef]

131. Allegra, D.; Bilan, V.; Garding, A.; Dohner, H.; Stilgenbauer, S.; Kuchenbauer, F.; Mertens, D.; Zucknick, M. Defective DROSHA processing contributes to downregulation of MiR-15/-16 in chronic lymphocytic leukemia. Leukemia 2014, 28, 98-107. [CrossRef] [PubMed]

132. Gagnon, J.D.; Kageyama, R.; Shehata, H.M.; Fassett, M.S.; Mar, D.J.; Wigton, E.J.; Johansson, K.; Litterman, A.J.; Odorizzi, P.; Simeonov, D.; et al. miR-15/16 Restrain Memory T Cell Differentiation, Cell Cycle, and Survival. Cell Rep. 2019, 28, 2169-2181.e4. [CrossRef]

133. Musumeci, M.; Coppola, V.; Addario, A.; Patrizii, M.; Maugeri-Sacca, M.; Memeo, L.; Colarossi, C.; Francescangeli, F.; Biffoni, M.; Collura, D.; et al. Control of tumor and microenvironment cross-talk by miR-15a and miR-16 in prostate cancer. Oncogene 2011, 30, 4231-4242. [CrossRef] [PubMed]

134. Reid, G.; Pel, M.E.; Kirschner, M.B.; Cheng, Y.Y.; Mugridge, N.; Weiss, J.; Williams, M.; Wright, C.; Edelman, J.J.; Vallely, M.P.; et al. Restoring expression of miR-16: A novel approach to therapy for malignant pleural mesothelioma. Ann. Oncol. 2013, 24, 3128-3135. [CrossRef]

135. Martinez, I.; Cazalla, D.; Almstead, L.L.; Steitz, J.A.; DiMaio, D. miR-29 and miR-30 regulate B-Myb expression during cellular senescence. Proc. Natl. Acad. Sci. USA 2011, 108, 522-527. [CrossRef] [PubMed]

136. Campbell, K.J.; Dhayade, S.; Ferrari, N.; Sims, A.H.; Johnson, E.; Mason, S.M.; Dickson, A.; Ryan, K.M.; Kalna, G.; Edwards, J.; et al. MCL-1 is a prognostic indicator and drug target in breast cancer. Cell Death Dis. 2018, 9, 19. [CrossRef]

137. Placzek, W.J.; Wei, J.; Kitada, S.; Zhai, D.; Reed, J.C.; Pellecchia, M. A survey of the anti-apoptotic Bcl-2 subfamily expression in cancer types provides a platform to predict the efficacy of Bcl-2 antagonists in cancer therapy. Cell Death Dis. 2010, 1, e40. [CrossRef] [PubMed]

138. Akgul, C. Mcl-1 is a potential therapeutic target in multiple types of cancer. Cell. Mol. Life Sci. 2009, 66, 1326-1336. [CrossRef] [PubMed]

139. Hermeking, H. The miR-34 family in cancer and apoptosis. Cell Death Differ. 2010, 17, 193-199. [CrossRef]

140. Korpal, M.; Kang, Y. The emerging role of miR-200 family of microRNAs in epithelial-mesenchymal transition and cancer metastasis. RNA Biol. 2008, 5, 115-119. [CrossRef]

141. Johnson, S.M.; Grosshans, H.; Shingara, J.; Byrom, M.; Jarvis, R.; Cheng, A.; Labourier, E.; Reinert, K.L.; Brown, D.; Slack, F.J. RAS is regulated by the let-7 microRNA family. Cell 2005, 120, 635-647. [CrossRef] [PubMed]

142. Medina, P.P.; Nolde, M.; Slack, F.J. OncomiR addiction in an in vivo model of microRNA-21-induced pre-B-cell lymphoma. Nature 2010, 467, 86-90. [CrossRef] [PubMed]

143. Chan, J.A.; Krichevsky, A.M.; Kosik, K.S. MicroRNA-21 is an antiapoptotic factor in human glioblastoma cells. Cancer Res. 2005, 65, 6029-6033. [CrossRef]

144. Fulci, V.; Chiaretti, S.; Goldoni, M.; Azzalin, G.; Carucci, N.; Tavolaro, S.; Castellano, L.; Magrelli, A.; Citarella, F.; Messina, M.; et al. Quantitative technologies establish a novel microRNA profile of chronic lymphocytic leukemia. Blood 2007, 109, 4944-4951. [CrossRef] [PubMed]

145. Eis, P.S.; Tam, W.; Sun, L.; Chadburn, A.; Li, Z.; Gomez, M.F.; Lund, E.; Dahlberg, J.E. Accumulation of miR-155 and BIC RNA in human B cell lymphomas. Proc. Natl. Acad. Sci. USA 2005, 102, 3627-3632. [CrossRef] [PubMed]

146. O’Donnell, K.A.; Wentzel, E.A.; Zeller, K.I.; Dang, C.V.; Mendell, J.T. c-Myc-regulated microRNAs modulate E2F1 expression. Nature 2005, 435, 839-843. [CrossRef]

147. Hayashita, Y.; Osada, H.; Tatematsu, Y.; Yamada, H.; Yanagisawa, K.; Tomida, S.; Yatabe, Y.; Kawahara, K.; Sekido, Y.; Takahashi, T. A polycistronic microRNA cluster, miR-17-92, is overexpressed in human lung cancers and enhances cell proliferation. Cancer Res. 2005, 65, 9628-9632. [CrossRef]

148. O'Connell, R.M.; Chaudhuri, A.A.; Rao, D.S.; Baltimore, D. Inositol phosphatase SHIP1 is a primary target of miR-155. Proc. Natl. Acad. Sci. USA 2009, 106, 7113-7118. [CrossRef] [PubMed]

149. Cheng, C.J.; Slack, F.J. The duality of oncomiR addiction in the maintenance and treatment of cancer. Cancer J. 2012, 18, $232-237$. [CrossRef] [PubMed]

150. Wu, X.; Pan, Y.; Fang, Y.; Zhang, J.; Xie, M.; Yang, F.; Yu, T.; Ma, P.; Li, W.; Shu, Y. The Biogenesis and Functions of piRNAs in Human Diseases. Mol. Ther. Nucleic Acids 2020, 21, 108-120. [CrossRef] [PubMed]

151. Suzuki, R.; Honda, S.; Kirino, Y. PIWI Expression and Function in Cancer. Front. Genet. 2012, 3, 204. [CrossRef] [PubMed] 
152. Li, F.; Yuan, P.; Rao, M.; Jin, C.H.; Tang, W.; Rong, Y.F.; Hu, Y.P.; Zhang, F.; Wei, T.; Yin, Q.; et al. piRNA-independent function of PIWIL1 as a co-activator for anaphase promoting complex/cyclosome to drive pancreatic cancer metastasis. Nat. Cell Biol. 2020, 22, 425-438. [CrossRef] [PubMed]

153. Genzor, P.; Cordts, S.C.; Bokil, N.V.; Haase, A.D. Aberrant expression of select piRNA-pathway genes does not reactivate piRNA silencing in cancer cells. Proc. Natl. Acad. Sci. USA 2019, 116, 11111-11112. [CrossRef] [PubMed]

154. Fathizadeh, H.; Asemi, Z. Epigenetic roles of PIWI proteins and piRNAs in lung cancer. Cell Biosci. 2019, 9, 102. [CrossRef] [PubMed]

155. Assumpcao, C.B.; Calcagno, D.Q.; Araujo, T.M.; Santos, S.E.; Santos, A.K.; Riggins, G.J.; Burbano, R.R.; Assumpcao, P.P. The role of piRNA and its potential clinical implications in cancer. Epigenomics 2015, 7, 975-984. [CrossRef] [PubMed]

156. Martinez, V.D.; Vucic, E.A.; Thu, K.L.; Hubaux, R.; Enfield, K.S.; Pikor, L.A.; Becker-Santos, D.D.; Brown, C.J.; Lam, S.; Lam, W.L. Unique somatic and malignant expression patterns implicate PIWI-interacting RNAs in cancer-type specific biology. Sci. Rep. 2015, 5, 10423. [CrossRef]

157. Fu, A.; Jacobs, D.I.; Zhu, Y. Epigenome-wide analysis of piRNAs in gene-specific DNA methylation. RNA Biol. 2014, 11, 1301-1312. [CrossRef]

158. Lee, Y.J.; Moon, S.U.; Park, M.G.; Jung, W.Y.; Park, Y.K.; Song, S.K.; Ryu, J.G.; Lee, Y.S.; Heo, H.J.; Gu, H.N.; et al. Multiplex bioimaging of piRNA molecular pathway-regulated theragnostic effects in a single breast cancer cell using a piRNA molecular beacon. Biomaterials 2016, 101, 143-155. [CrossRef] [PubMed]

159. Carlevaro-Fita, J.; Lanzos, A.; Feuerbach, L.; Hong, C.; Mas-Ponte, D.; Pedersen, J.S.; Drivers, P.; Functional Interpretation, G.; Johnson, R.; Consortium, P. Cancer LncRNA Census reveals evidence for deep functional conservation of long noncoding RNAs in tumorigenesis. Commun. Biol. 2020, 3, 56. [CrossRef] [PubMed]

160. Poliseno, L. Pseudogenes: Newly discovered players in human cancer. Sci. Signal. 2012, 5, re5. [CrossRef]

161. Zhang, Q.; Wang, W.; Zhou, Q.; Chen, C.; Yuan, W.; Liu, J.; Li, X.; Sun, Z. Roles of circRNAs in the tumour microenvironment. Mol. Cancer 2020, 19, 14. [CrossRef]

162. Patop, I.L.; Kadener, S. circRNAs in Cancer. Curr. Opin. Genet. Dev. 2018, 48, 121-127. [CrossRef] [PubMed]

163. Bach, D.H.; Lee, S.K.; Sood, A.K. Circular RNAs in Cancer. Mol. Ther. Nucleic Acids 2019, 16, 118-129. [CrossRef] [PubMed]

164. Bachmayr-Heyda, A.; Reiner, A.T.; Auer, K.; Sukhbaatar, N.; Aust, S.; Bachleitner-Hofmann, T.; Mesteri, I.; Grunt, T.W.; Zeillinger, R.; Pils, D. Correlation of circular RNA abundance with proliferation-Exemplified with colorectal and ovarian cancer, idiopathic lung fibrosis, and normal human tissues. Sci. Rep. 2015, 5, 8057. [CrossRef]

165. Bade, B.C.; Dela Cruz, C.S. Lung Cancer 2020: Epidemiology, Etiology, and Prevention. Clin. Chest. Med. 2020, 41, 1-24. [CrossRef] [PubMed]

166. Bray, F.; Ferlay, J.; Soerjomataram, I.; Siegel, R.L.; Torre, L.A.; Jemal, A. Global cancer statistics 2018: GLOBOCAN estimates of incidence and mortality worldwide for 36 cancers in 185 countries. CA Cancer J. Clin. 2018, 68, 394-424. [CrossRef] [PubMed]

167. Siegel, R.L.; Miller, K.D.; Jemal, A. Cancer statistics, 2020. CA Cancer J. Clin. 2020, 70, 7-30. [CrossRef]

168. Travis, W.D.; Brambilla, E.; Noguchi, M.; Nicholson, A.G.; Geisinger, K.R.; Yatabe, Y.; Beer, D.G.; Powell, C.A.; Riely, G.J.; Van Schil, P.E.; et al. International association for the study of lung cancer/american thoracic society/european respiratory society international multidisciplinary classification of lung adenocarcinoma. J. Thorac. Oncol. 2011, 6, 244-285. [CrossRef] [PubMed]

169. Ji, P.; Diederichs, S.; Wang, W.; Boing, S.; Metzger, R.; Schneider, P.M.; Tidow, N.; Brandt, B.; Buerger, H.; Bulk, E.; et al. MALAT-1, a novel noncoding RNA, and thymosin beta4 predict metastasis and survival in early-stage non-small cell lung cancer. Oncogene 2003, 22, 8031-8041. [CrossRef] [PubMed]

170. Zhang, X.; Hamblin, M.H.; Yin, K.J. The long noncoding RNA Malat1: Its physiological and pathophysiological functions. RNA Biol. 2017, 14, 1705-1714. [CrossRef] [PubMed]

171. Hutchinson, J.N.; Ensminger, A.W.; Clemson, C.M.; Lynch, C.R.; Lawrence, J.B.; Chess, A. A screen for nuclear transcripts identifies two linked noncoding RNAs associated with SC35 splicing domains. BMC Genom. 2007, 8, 39. [CrossRef] [PubMed]

172. Tano, K.; Mizuno, R.; Okada, T.; Rakwal, R.; Shibato, J.; Masuo, Y.; Ijiri, K.; Akimitsu, N. MALAT-1 enhances cell motility of lung adenocarcinoma cells by influencing the expression of motility-related genes. FEBS Lett. 2010, 584, 4575-4580. [CrossRef] [PubMed]

173. Gutschner, T.; Hammerle, M.; Eissmann, M.; Hsu, J.; Kim, Y.; Hung, G.; Revenko, A.; Arun, G.; Stentrup, M.; Gross, M.; et al. The noncoding RNA MALAT1 is a critical regulator of the metastasis phenotype of lung cancer cells. Cancer Res. 2013, 73, 1180-1189. [CrossRef]

174. Shen, L.; Chen, L.; Wang, Y.; Jiang, X.; Xia, H.; Zhuang, Z. Long noncoding RNA MALAT1 promotes brain metastasis by inducing epithelial-mesenchymal transition in lung cancer. J. Neurooncol 2015, 121, 101-108. [CrossRef]

175. Gutschner, T.; Hammerle, M.; Diederichs, S. MALAT1-A paradigm for long noncoding RNA function in cancer. J. Mol. Med. (Berl) 2013, 91, 791-801. [CrossRef] [PubMed]

176. Takamizawa, J.; Konishi, H.; Yanagisawa, K.; Tomida, S.; Osada, H.; Endoh, H.; Harano, T.; Yatabe, Y.; Nagino, M.; Nimura, Y.; et al. Reduced expression of the let-7 microRNAs in human lung cancers in association with shortened postoperative survival. Cancer Res. 2004, 64, 3753-3756. [CrossRef]

177. Kumar, M.S.; Erkeland, S.J.; Pester, R.E.; Chen, C.Y.; Ebert, M.S.; Sharp, P.A.; Jacks, T. Suppression of non-small cell lung tumor development by the let-7 microRNA family. Proc. Natl. Acad. Sci. USA 2008, 105, 3903-3908. [CrossRef] [PubMed] 
178. Kumar, M.S.; Armenteros-Monterroso, E.; East, P.; Chakravorty, P.; Matthews, N.; Winslow, M.M.; Downward, J. HMGA2 functions as a competing endogenous RNA to promote lung cancer progression. Nature 2014, 505, 212-217. [CrossRef] [PubMed]

179. Daugaard, I.; Knudsen, A.; Kjeldsen, T.E.; Hager, H.; Hansen, L.L. The association between miR-34 dysregulation and distant metastases formation in lung adenocarcinoma. Exp. Mol. Pathol. 2017, 102, 484-491. [CrossRef]

180. Kim, J.S.; Kim, E.J.; Lee, S.; Tan, X.; Liu, X.; Park, S.; Kang, K.; Yoon, J.S.; Ko, Y.H.; Kurie, J.M.; et al. MiR-34a and miR-34b/c have distinct effects on the suppression of lung adenocarcinomas. Exp. Mol. Med. 2019, 51, 1-10. [CrossRef]

181. Mizuno, K.; Mataki, H.; Arai, T.; Okato, A.; Kamikawaji, K.; Kumamoto, T.; Hiraki, T.; Hatanaka, K.; Inoue, H.; Seki, N. The microRNA expression signature of small cell lung cancer: Tumor suppressors of miR-27a-5p and miR-34b-3p and their targeted oncogenes. J. Hum. Genet. 2017, 62, 671-678. [CrossRef] [PubMed]

182. Huang, W.; Yan, Y.; Liu, Y.; Lin, M.; Ma, J.; Zhang, W.; Dai, J.; Li, J.; Guo, Q.; Chen, H.; et al. Exosomes with low miR-34c-3p expression promote invasion and migration of non-small cell lung cancer by upregulating integrin alpha2beta1. Signal Transduct. Target. Ther. 2020, 5, 39. [CrossRef]

183. Cortez, M.A.; Ivan, C.; Valdecanas, D.; Wang, X.; Peltier, H.J.; Ye, Y.; Araujo, L.; Carbone, D.P.; Shilo, K.; Giri, D.K.; et al. PDL1 Regulation by 553 via miR-34. J. Natl. Cancer Inst. 2016, 108. [CrossRef] [PubMed]

184. Vencken, S.F.; Greene, C.M.; McKiernan, P.J. Non-coding RNA as lung disease biomarkers. Thorax 2015, 70, 501-503. [CrossRef]

185. Yang, Y.; Meng, H.; Peng, Q.; Yang, X.; Gan, R.; Zhao, L.; Chen, Z.; Lu, J.; Meng, Q.H. Downregulation of microRNA-21 expression restrains non-small cell lung cancer cell proliferation and migration through upregulation of programmed cell death 4 . Cancer Gene Ther. 2015, 22, 23-29. [CrossRef] [PubMed]

186. Frezzetti, D.; De Menna, M.; Zoppoli, P.; Guerra, C.; Ferraro, A.; Bello, A.M.; De Luca, P.; Calabrese, C.; Fusco, A.; Ceccarelli, M.; et al. Upregulation of miR-21 by Ras in vivo and its role in tumor growth. Oncogene 2011, 30, 275-286. [CrossRef] [PubMed]

187. Liu, X.H.; Liu, Z.L.; Sun, M.; Liu, J.; Wang, Z.X.; De, W. The long non-coding RNA HOTAIR indicates a poor prognosis and promotes metastasis in non-small cell lung cancer. BMC Cancer 2013, 13, 464. [CrossRef] [PubMed]

188. Loewen, G.; Jayawickramarajah, J.; Zhuo, Y.; Shan, B. Functions of lncRNA HOTAIR in lung cancer. J. Hematol. Oncol. 2014, 7, 90. [CrossRef] [PubMed]

189. Ono, H.; Motoi, N.; Nagano, H.; Miyauchi, E.; Ushijima, M.; Matsuura, M.; Okumura, S.; Nishio, M.; Hirose, T.; Inase, N.; et al. Long noncoding RNA HOTAIR is relevant to cellular proliferation, invasiveness, and clinical relapse in small-cell lung cancer. Cancer Med. 2014, 3, 632-642. [CrossRef]

190. Lu, K.H.; Li, W.; Liu, X.H.; Sun, M.; Zhang, M.L.; Wu, W.Q.; Xie, W.P.; Hou, Y.Y. Long non-coding RNA MEG3 inhibits NSCLC cells proliferation and induces apoptosis by affecting p53 expression. BMC Cancer 2013, 13, 461. [CrossRef]

191. Sun, R.; Wang, R.; Chang, S.; Li, K.; Sun, R.; Wang, M.; Li, Z. Long Non-Coding RNA in Drug Resistance of Non-Small Cell Lung Cancer: A Mini Review. Front. Pharmacol. 2019, 10, 1457. [CrossRef] [PubMed]

192. Zhang, X.; Xie, K.; Zhou, H.; Wu, Y.; Li, C.; Liu, Y.; Liu, Z.; Xu, Q.; Liu, S.; Xiao, D.; et al. Role of non-coding RNAs and RNA modifiers in cancer therapy resistance. Mol. Cancer 2020, 19, 47. [CrossRef] [PubMed]

193. Liu, K.; Gao, L.; Ma, X.; Huang, J.J.; Chen, J.; Zeng, L.; Ashby, C.R., Jr.; Zou, C.; Chen, Z.S. Long non-coding RNAs regulate drug resistance in cancer. Mol. Cancer 2020, 19, 54. [CrossRef]

194. Sun, W.; Zu, Y.; Fu, X.; Deng, Y. Knockdown of lncRNA-XIST enhances the chemosensitivity of NSCLC cells via suppression of autophagy. Oncol. Rep. 2017, 38, 3347-3354. [CrossRef]

195. Dong, S.; Qu, X.; Li, W.; Zhong, X.; Li, P.; Yang, S.; Chen, X.; Shao, M.; Zhang, L. The long non-coding RNA, GAS5, enhances gefitinib-induced cell death in innate EGFR tyrosine kinase inhibitor-resistant lung adenocarcinoma cells with wide-type EGFR via downregulation of the IGF-1R expression. J. Hematol. Oncol. 2015, 8, 43. [CrossRef] [PubMed]

196. Qiu, M.; Xu, Y.; Wang, J.; Zhang, E.; Sun, M.; Zheng, Y.; Li, M.; Xia, W.; Feng, D.; Yin, R.; et al. A novel lncRNA, LUADT1, promotes lung adenocarcinoma proliferation via the epigenetic suppression of p27. Cell Death Dis. 2015, 6, e1858. [CrossRef] [PubMed]

197. Wang, J.; Zhao, X.; Wang, Y.; Ren, F.; Sun, D.; Yan, Y.; Kong, X.; Bu, J.; Liu, M.; Xu, S. circRNA-002178 act as a ceRNA to promote PDL1/PD1 expression in lung adenocarcinoma. Cell Death Dis. 2020, 11, 32. [CrossRef]

198. Stewart, G.L.; Enfield, K.S.S.; Sage, A.P.; Martinez, V.D.; Minatel, B.C.; Pewarchuk, M.E.; Marshall, E.A.; Lam, W.L. Aberrant Expression of Pseudogene-Derived lncRNAs as an Alternative Mechanism of Cancer Gene Regulation in Lung Adenocarcinoma. Front. Genet. 2019, 10, 138. [CrossRef] [PubMed]

199. Goossens, N.; Nakagawa, S.; Sun, X.; Hoshida, Y. Cancer biomarker discovery and validation. Transl Cancer Res. 2015, 4, 256-269. [CrossRef]

200. Qi, P.; Du, X. The long non-coding RNAs, a new cancer diagnostic and therapeutic gold mine. Mod. Pathol. 2013, 26, 155-165. [CrossRef]

201. Voigt, W.; Manegold, C.; Pilz, L.; Wu, Y.L.; Mullauer, L.; Pirker, R.; Filipits, M.; Niklinski, J.; Petruzelka, L.; Prosch, H. Beyond tissue biopsy: A diagnostic framework to address tumor heterogeneity in lung cancer. Curr. Opin. Oncol. 2020, 32, 68-77. [CrossRef] [PubMed]

202. Ilie, M.; Hofman, P. Pros: Can tissue biopsy be replaced by liquid biopsy? Transl. Lung Cancer Res. 2016, 5, 420-423. [CrossRef] [PubMed]

203. Mino-Kenudson, M. Cons: Can liquid biopsy replace tissue biopsy?-the US experience. Transl. Lung Cancer Res. $2016,5,424-427$. [CrossRef] [PubMed] 
204. Gerlinger, M.; Rowan, A.J.; Horswell, S.; Math, M.; Larkin, J.; Endesfelder, D.; Gronroos, E.; Martinez, P.; Matthews, N.; Stewart, A.; et al. Intratumor heterogeneity and branched evolution revealed by multiregion sequencing. N. Engl. J. Med. 2012, 366, 883-892. [CrossRef]

205. Mitchell, P.S.; Parkin, R.K.; Kroh, E.M.; Fritz, B.R.; Wyman, S.K.; Pogosova-Agadjanyan, E.L.; Peterson, A.; Noteboom, J.; O’Briant, K.C.; Allen, A.; et al. Circulating microRNAs as stable blood-based markers for cancer detection. Proc. Natl. Acad. Sci. USA 2008, 105, 10513-10518. [CrossRef]

206. Chen, X.; Ba, Y.; Ma, L.; Cai, X.; Yin, Y.; Wang, K.; Guo, J.; Zhang, Y.; Chen, J.; Guo, X.; et al. Characterization of microRNAs in serum: A novel class of biomarkers for diagnosis of cancer and other diseases. Cell Res. 2008, 18, 997-1006. [CrossRef] [PubMed]

207. Fernandez-Mercado, M.; Manterola, L.; Larrea, E.; Goicoechea, I.; Arestin, M.; Armesto, M.; Otaegui, D.; Lawrie, C.H. The circulating transcriptome as a source of non-invasive cancer biomarkers: Concepts and controversies of non-coding and coding RNA in body fluids. J. Cell. Mol. Med. 2015, 19, 2307-2323. [CrossRef]

208. Wan, J.C.M.; Massie, C.; Garcia-Corbacho, J.; Mouliere, F.; Brenton, J.D.; Caldas, C.; Pacey, S.; Baird, R.; Rosenfeld, N. Liquid biopsies come of age: Towards implementation of circulating tumour DNA. Nat. Rev. Cancer 2017, 17, 223-238. [CrossRef] [PubMed]

209. Fatima, F.; Nawaz, M. Vesiculated Long Non-Coding RNAs: Offshore Packages Deciphering Trans-Regulation between Cells, Cancer Progression and Resistance to Therapies. Noncoding RNA 2017, 3, 10. [CrossRef] [PubMed]

210. Hanna, J.; Hossain, G.S.; Kocerha, J. The Potential for microRNA Therapeutics and Clinical Research. Front. Genet. 2019, 10, 478. [CrossRef] [PubMed]

211. Gustafson, D.; Tyryshkin, K.; Renwick, N. microRNA-guided diagnostics in clinical samples. Best Pract. Res. Clin. Endocrinol. Metab. 2016, 30, 563-575. [CrossRef]

212. Bussemakers, M.J.; van Bokhoven, A.; Verhaegh, G.W.; Smit, F.P.; Karthaus, H.F.; Schalken, J.A.; Debruyne, F.M.; Ru, N.; Isaacs, W.B. DD3: A new prostate-specific gene, highly overexpressed in prostate cancer. Cancer Res. 1999, 59, 5975-5979.

213. Hessels, D.; Klein Gunnewiek, J.M.; van Oort, I.; Karthaus, H.F.; van Leenders, G.J.; van Balken, B.; Kiemeney, L.A.; Witjes, J.A.; Schalken, J.A. DD3(PCA3)-based molecular urine analysis for the diagnosis of prostate cancer. Eur. Urol. 2003, 44, 8-15; discussion 15-16. [CrossRef]

214. Groskopf, J.; Aubin, S.M.; Deras, I.L.; Blase, A.; Bodrug, S.; Clark, C.; Brentano, S.; Mathis, J.; Pham, J.; Meyer, T.; et al. APTIMA PCA3 molecular urine test: Development of a method to aid in the diagnosis of prostate cancer. Clin. Chem. 2006, 52, 1089-1095. [CrossRef] [PubMed]

215. Marks, L.S.; Bostwick, D.G. Prostate Cancer Specificity of PCA3 Gene Testing: Examples from Clinical Practice. Rev. Urol. 2008, 10, 175-181.

216. Lee, G.L.; Dobi, A.; Srivastava, S. Prostate cancer: Diagnostic performance of the PCA3 urine test. Nat. Rev. Urol. 2011, 8, 123-124. [CrossRef]

217. Hou, J.; Meng, F.; Chan, L.W.; Cho, W.C.; Wong, S.C. Circulating Plasma MicroRNAs As Diagnostic Markers for NSCLC. Front. Genet. 2016, 7, 193. [CrossRef] [PubMed]

218. Pine, S.R.; Ryan, B.M. Identifying therapeutic vulnerabilities in lung cancer: Application of a chemistry-first approach. Transl. Lung Cancer Res. 2018, 7, S265-S269. [CrossRef]

219. David, E.A.; Daly, M.E.; Li, C.S.; Chiu, C.L.; Cooke, D.T.; Brown, L.M.; Melnikow, J.; Kelly, K.; Canter, R.J. Increasing Rates of No Treatment in Advanced-Stage Non-Small Cell Lung Cancer Patients: A Propensity-Matched Analysis. J. Thorac. Oncol. 2017, 12, 437-445. [CrossRef]

220. Borondy Kitts, A.K. The Patient Perspective on Lung Cancer Screening and Health Disparities. J. Am. Coll. Radiol. 2019, 16, 601-606. [CrossRef]

221. Chu, G.C.W.; Lazare, K.; Sullivan, F. Serum and blood based biomarkers for lung cancer screening: A systematic review. BMC Cancer 2018, 18, 181. [CrossRef]

222. Dou, Y.; Zhu, Y.; Ai, J.; Chen, H.; Liu, H.; Borgia, J.A.; Li, X.; Yang, F.; Jiang, B.; Wang, J.; et al. Plasma small ncRNA pair panels as novel biomarkers for early-stage lung adenocarcinoma screening. BMC Genom. 2018, 19, 545. [CrossRef]

223. Zaporozhchenko, I.A.; Morozkin, E.S.; Ponomaryova, A.A.; Rykova, E.Y.; Cherdyntseva, N.V.; Zheravin, A.A.; Pashkovskaya, O.A.; Pokushalov, E.A.; Vlassov, V.V.; Laktionov, P.P. Profiling of 179 miRNA Expression in Blood Plasma of Lung Cancer Patients and Cancer-Free Individuals. Sci. Rep. 2018, 8, 6348. [CrossRef] [PubMed]

224. Lin, Y.; Leng, Q.; Zhan, M.; Jiang, F. A Plasma Long Noncoding RNA Signature for Early Detection of Lung Cancer. Transl. Oncol. 2018, 11, 1225-1231. [CrossRef]

225. Jin, X.; Chen, Y.; Chen, H.; Fei, S.; Chen, D.; Cai, X.; Liu, L.; Lin, B.; Su, H.; Zhao, L.; et al. Evaluation of Tumor-Derived Exosomal miRNA as Potential Diagnostic Biomarkers for Early-Stage Non-Small Cell Lung Cancer Using Next-Generation Sequencing. Clin. Cancer Res. 2017, 23, 5311-5319. [CrossRef] [PubMed]

226. Wang, C.; Tan, S.; Liu, W.R.; Lei, Q.; Qiao, W.; Wu, Y.; Liu, X.; Cheng, W.; Wei, Y.Q.; Peng, Y.; et al. RNA-Seq profiling of circular RNA in human lung adenocarcinoma and squamous cell carcinoma. Mol. Cancer 2019, 18, 134. [CrossRef] [PubMed]

227. Grimolizzi, F.; Monaco, F.; Leoni, F.; Bracci, M.; Staffolani, S.; Bersaglieri, C.; Gaetani, S.; Valentino, M.; Amati, M.; Rubini, C.; et al. Exosomal miR-126 as a circulating biomarker in non-small-cell lung cancer regulating cancer progression. Sci. Rep. 2017, 7, 15277. [CrossRef] [PubMed] 
228. Best, M.G.; Sol, N.; In ‘t Veld, S.; Vancura, A.; Muller, M.; Niemeijer, A.N.; Fejes, A.V.; Tjon Kon Fat, L.A.; Huis In ‘t Veld, A.E.; Leurs, C.; et al. Swarm Intelligence-Enhanced Detection of Non-Small-Cell Lung Cancer Using Tumor-Educated Platelets. Cancer Cell 2017, 32, 238-252.e9. [CrossRef]

229. Nigita, G.; Distefano, R.; Veneziano, D.; Romano, G.; Rahman, M.; Wang, K.; Pass, H.; Croce, C.M.; Acunzo, M.; Nana-Sinkam, P. Tissue and exosomal miRNA editing in Non-Small Cell Lung Cancer. Sci. Rep. 2018, 8, 10222. [CrossRef]

230. Maemura, K.; Watanabe, K.; Ando, T.; Hiyama, N.; Sakatani, T.; Amano, Y.; Kage, H.; Nakajima, J.; Yatomi, Y.; Nagase, T.; et al. Altered editing level of microRNAs is a potential biomarker in lung adenocarcinoma. Cancer Sci. 2018, 109, 3326-3335. [CrossRef] [PubMed]

231. Asakura, K.; Kadota, T.; Matsuzaki, J.; Yoshida, Y.; Yamamoto, Y.; Nakagawa, K.; Takizawa, S.; Aoki, Y.; Nakamura, E.; Miura, J.; et al. A miRNA-based diagnostic model predicts resectable lung cancer in humans with high accuracy. Commun. Biol. 2020, 3, 134. [CrossRef]

232. Schmidt, L.H.; Spieker, T.; Koschmieder, S.; Schaffers, S.; Humberg, J.; Jungen, D.; Bulk, E.; Hascher, A.; Wittmer, D.; Marra, A.; et al. The long noncoding MALAT-1 RNA indicates a poor prognosis in non-small cell lung cancer and induces migration and tumor growth. J. Thorac. Oncol. 2011, 6, 1984-1992. [CrossRef] [PubMed]

233. Pinto, Y.; Buchumenski, I.; Levanon, E.Y.; Eisenberg, E. Human cancer tissues exhibit reduced A-to-I editing of miRNAs coupled with elevated editing of their targets. Nucleic Acids Res. 2018, 46, 71-82. [CrossRef] [PubMed]

234. Lieberman, J. Tapping the RNA world for therapeutics. Nat. Struct. Mol. Biol. 2018, 25, 357-364. [CrossRef]

235. Kaczmarek, J.C.; Kowalski, P.S.; Anderson, D.G. Advances in the delivery of RNA therapeutics: From concept to clinical reality. Genome Med. 2017, 9, 60. [CrossRef]

236. Soutschek, J.; Akinc, A.; Bramlage, B.; Charisse, K.; Constien, R.; Donoghue, M.; Elbashir, S.; Geick, A.; Hadwiger, P.; Harborth, J.; et al. Therapeutic silencing of an endogenous gene by systemic administration of modified siRNAs. Nature 2004, 432, 173-178. [CrossRef] [PubMed]

237. Rupaimoole, R.; Slack, F.J. MicroRNA therapeutics: Towards a new era for the management of cancer and other diseases. Nat Rev. Drug Discov. 2017, 16, 203-222. [CrossRef] [PubMed]

238. Beg, M.S.; Brenner, A.J.; Sachdev, J.; Borad, M.; Kang, Y.K.; Stoudemire, J.; Smith, S.; Bader, A.G.; Kim, S.; Hong, D.S. Phase I study of MRX34, a liposomal miR-34a mimic, administered twice weekly in patients with advanced solid tumors. Investig. New Drugs 2017, 35, 180-188. [CrossRef] [PubMed]

239. Reid, G.; Kao, S.C.; Pavlakis, N.; Brahmbhatt, H.; MacDiarmid, J.; Clarke, S.; Boyer, M.; van Zandwijk, N. Clinical development of TargomiRs, a miRNA mimic-based treatment for patients with recurrent thoracic cancer. Epigenomics 2016, 8, 1079-1085. [CrossRef] [PubMed]

240. van Zandwijk, N.; Pavlakis, N.; Kao, S.C.; Linton, A.; Boyer, M.J.; Clarke, S.; Huynh, Y.; Chrzanowska, A.; Fulham, M.J.; Bailey, D.L.; et al. Safety and activity of microRNA-loaded minicells in patients with recurrent malignant pleural mesothelioma: A first-in-man, phase 1, open-label, dose-escalation study. Lancet Oncol. 2017, 18, 1386-1396. [CrossRef]

241. Kannan, R.M. Toward new design principles for superior gene silencing. Proc. Natl. Acad. Sci. USA 2018, 115, 3200-3201. [CrossRef]

242. Grimm, D. Small silencing RNAs: State-of-the-art. Adv. Drug Deliv. Rev. 2009, 61, 672-703. [CrossRef] [PubMed]

243. Acunzo, M.; Romano, G.; Nigita, G.; Veneziano, D.; Fattore, L.; Lagana, A.; Zanesi, N.; Fadda, P.; Fassan, M.; Rizzotto, L.; et al. Selective targeting of point-mutated KRAS through artificial microRNAs. Proc. Natl. Acad. Sci. USA 2017, 114, E4203-E4212. [CrossRef] [PubMed]

244. Ozcan, G.; Ozpolat, B.; Coleman, R.L.; Sood, A.K.; Lopez-Berestein, G. Preclinical and clinical development of siRNA-based therapeutics. Adv. Drug Deliv. Rev. 2015, 87, 108-119. [CrossRef] [PubMed]

245. Schultheis, B.; Strumberg, D.; Santel, A.; Vank, C.; Gebhardt, F.; Keil, O.; Lange, C.; Giese, K.; Kaufmann, J.; Khan, M.; et al. First-in-human phase I study of the liposomal RNA interference therapeutic Atu027 in patients with advanced solid tumors. J. Clin. Oncol. 2014, 32, 4141-4148. [CrossRef] [PubMed]

246. Golan, T.; Khvalevsky, E.Z.; Hubert, A.; Gabai, R.M.; Hen, N.; Segal, A.; Domb, A.; Harari, G.; David, E.B.; Raskin, S.; et al. RNAi therapy targeting KRAS in combination with chemotherapy for locally advanced pancreatic cancer patients. Oncotarget 2015, 6, 24560-24570. [CrossRef] [PubMed]

247. El Dika, I.; Lim, H.Y.; Yong, W.P.; Lin, C.C.; Yoon, J.H.; Modiano, M.; Freilich, B.; Choi, H.J.; Chao, T.Y.; Kelley, R.K.; et al. An OpenLabel, Multicenter, Phase I, Dose Escalation Study with Phase II Expansion Cohort to Determine the Safety, Pharmacokinetics, and Preliminary Antitumor Activity of Intravenous TKM-080301 in Subjects with Advanced Hepatocellular Carcinoma. Oncologist 2019, 24, 747-e218. [CrossRef] [PubMed]

248. Wagner, M.J.; Mitra, R.; McArthur, M.J.; Baze, W.; Barnhart, K.; Wu, S.Y.; Rodriguez-Aguayo, C.; Zhang, X.; Coleman, R.L.; Lopez-Berestein, G.; et al. Preclinical Mammalian Safety Studies of EPHARNA (DOPC Nanoliposomal EphA2-Targeted siRNA). Mol. Cancer Ther. 2017, 16, 1114-1123. [CrossRef] [PubMed]

249. Krutzfeldt, J.; Rajewsky, N.; Braich, R.; Rajeev, K.G.; Tuschl, T.; Manoharan, M.; Stoffel, M. Silencing of microRNAs in vivo with 'antagomirs'. Nature 2005, 438, 685-689. [CrossRef]

250. Gebert, L.F.; Rebhan, M.A.; Crivelli, S.E.; Denzler, R.; Stoffel, M.; Hall, J. Miravirsen (SPC3649) can inhibit the biogenesis of miR-122. Nucleic Acids Res. 2014, 42, 609-621. [CrossRef] 
251. Seto, A.G.; Beatty, X.; Lynch, J.M.; Hermreck, M.; Tetzlaff, M.; Duvic, M.; Jackson, A.L. Cobomarsen, an oligonucleotide inhibitor of miR-155, co-ordinately regulates multiple survival pathways to reduce cellular proliferation and survival in cutaneous T-cell lymphoma. Br. J. Haematol. 2018, 183, 428-444. [CrossRef] [PubMed]

252. Obad, S.; dos Santos, C.O.; Petri, A.; Heidenblad, M.; Broom, O.; Ruse, C.; Fu, C.; Lindow, M.; Stenvang, J.; Straarup, E.M.; et al. Silencing of microRNA families by seed-targeting tiny LNAs. Nat. Genet. 2011, 43, 371-378. [CrossRef] [PubMed]

253. Cheng, C.J.; Bahal, R.; Babar, I.A.; Pincus, Z.; Barrera, F.; Liu, C.; Svoronos, A.; Braddock, D.T.; Glazer, P.M.; Engelman, D.M.; et al. MicroRNA silencing for cancer therapy targeted to the tumour microenvironment. Nature 2015, 518, 107-110. [CrossRef] [PubMed]

254. Li, J.; Wu, C.; Wang, W.; He, Y.; Elkayam, E.; Joshua-Tor, L.; Hammond, P.T. Structurally modulated codelivery of siRNA and Argonaute 2 for enhanced RNA interference. Proc. Natl. Acad. Sci. USA 2018, 115, E2696-E2705. [CrossRef] [PubMed]

255. Kasinski, A.L.; Slack, F.J. Epigenetics and genetics. MicroRNAs en route to the clinic: Progress in validating and targeting microRNAs for cancer therapy. Nat. Rev. Cancer 2011, 11, 849-864. [CrossRef]

256. Wang, J.; Lu, Z.; Wientjes, M.G.; Au, J.L. Delivery of siRNA therapeutics: Barriers and carriers. AAPS J. 2010, 12, 492-503. [CrossRef]

257. Lam, J.K.; Chow, M.Y.; Zhang, Y.; Leung, S.W. siRNA Versus miRNA as Therapeutics for Gene Silencing. Mol. Ther. Nucleic Acids 2015, 4, e252. [CrossRef] [PubMed]

258. Lagana, A.; Acunzo, M.; Romano, G.; Pulvirenti, A.; Veneziano, D.; Cascione, L.; Giugno, R.; Gasparini, P.; Shasha, D.; Ferro, A.; et al. miR-Synth: A computational resource for the design of multi-site multi-target synthetic miRNAs. Nucleic Acids Res. 2014, 42, 5416-5425. [CrossRef] [PubMed]

259. Trang, P.; Wiggins, J.F.; Daige, C.L.; Cho, C.; Omotola, M.; Brown, D.; Weidhaas, J.B.; Bader, A.G.; Slack, F.J. Systemic delivery of tumor suppressor microRNA mimics using a neutral lipid emulsion inhibits lung tumors in mice. Mol. Ther. 2011, 19, 1116-1122. [CrossRef]

260. Wiggins, J.F.; Ruffino, L.; Kelnar, K.; Omotola, M.; Patrawala, L.; Brown, D.; Bader, A.G. Development of a lung cancer therapeutic based on the tumor suppressor microRNA-34. Cancer Res. 2010, 70, 5923-5930. [CrossRef] [PubMed]

261. Xue, W.; Dahlman, J.E.; Tammela, T.; Khan, O.F.; Sood, S.; Dave, A.; Cai, W.; Chirino, L.M.; Yang, G.R.; Bronson, R.; et al. Small RNA combination therapy for lung cancer. Proc. Natl. Acad. Sci. USA 2014, 111, E3553-E3561. [CrossRef] [PubMed]

262. Perepelyuk, M.; Sacko, K.; Thangavel, K.; Shoyele, S.A. Evaluation of MUC1-Aptamer Functionalized Hybrid Nanoparticles for Targeted Delivery of miRNA-29b to Nonsmall Cell Lung Cancer. Mol. Pharm. 2018, 15, 985-993. [CrossRef] [PubMed]

263. Jeong, K.; Yu, Y.J.; You, J.Y.; Rhee, W.J.; Kim, J.A. Exosome-mediated microRNA-497 delivery for anti-cancer therapy in a microfluidic 3D lung cancer model. Lab. Chip. 2020, 20, 548-557. [CrossRef] [PubMed]

264. Bobbin, M.L.; Rossi, J.J. RNA Interference (RNAi)-Based Therapeutics: Delivering on the Promise? Annu. Rev. Pharmacol. Toxicol. 2016, 56, 103-122. [CrossRef] [PubMed] 